\title{
REGIMES OF ETHNICITY \\ Comparative Analysis of Germany, the Soviet Union/Post-Soviet Russia, and Turkey
}

\author{
By ŞENER AKTÜRK*
}

\section{The Puzzle of Persistence and Change in State Policies TOWARD ETHNICITY}

\begin{abstract}
$\mathrm{T}$ HIS article examines the dynamics of persistence and change in state policies toward ethnicity to answer the question: how do state policies that regulate the relationship between ethnicity and nationality change?
\end{abstract}

When Mahmut Erdem, a Turkish citizen of Kurdish descent and Shiite-Davidic faith, who had lived in Germany since the age of eight, was naturalized as a German citizen in 1989, he joined an exceptionally small category of people who acquired German citizenship without being ethnically German. ${ }^{1}$ As late as 1986 , twenty-five years after Germany began recruiting workers from Turkey, only 7,986 Turks were naturalized as German citizens, although nearly two million Turks lived in Germany. The situation was not different for the remaining 4,512,679 nonethnic German immigrants who had lived in Germany. ${ }^{2}$ Of Turks in Germany 99.5 percent were not German citizens, because

\footnotetext{
* I thank M. Steven Fish, J. Nicholas Ziegler, George W. Breslauer, Yuri Slezkine, Prerna Singh, Dmitry Gorenburg, Leonardo Arriola, Akasemi Newsome, Adnan Naseemullah, and three anonymous reviewers for World Politics, who read and commented on previous drafts of this article. Earlier versions of this article also benefitted from presentations at the comparative politics colloquium at the University of California, Berkeley, and the research workshop in comparative politics at Harvard University. The field research for this article was made possible by the John L. Simpson Memorial Research Fellowship in International and Comparative Studies from the Institute of International Studies at the University of California, Berkeley.

${ }^{1}$ Wernicke 1989.

${ }^{2}$ Bundesamt für Migration und Flüchtlinge 2004, 71, Table 25.
} 
since 1913 German citizenship law had conceived of citizenship as the right, or privilege, of ethnic Germans, allowing for the naturalization of nonethnic Germans only under very restrictive conditions. ${ }^{3}$ From the 1970s to the 1990s attempts to grant citizenship to resident aliens failed. However, a new citizenship law was passed in 1999, and by 2004 an estimated 840,000 Turks held German citizenship. ${ }^{4}$ How did a change of such magnitude occur?

As late as the 1980s it was a crime in Turkey to claim that "Kurds" exist because such a claim was equated with "separatism" and "terrorism." Kurds were described in official publications as Turks who had forgoten their origins and language ${ }^{5}$ or as "mountain Turks." ${ }^{6}$ The Labor Party was closed down in 1970 for declaring that a people called Kurds lived in Turkey. ${ }^{7}$ After the 1980 military coup it was argued that "Kurd is a sound that your boot makes when you walk on the snow." Şerafettin Elçi, a former minister of public works, was sentenced to two and a half years in prison for stating that "Kurds exist, and I am a Kurd." ${ }^{9}$ Yet in June 2004 Turkish state television, TRT, began broadcasting in Kurdish and four other minority languages (Arabic, Bosnian, Circassian, and Zaza). And in January 2009 TRT inaugurated an entire new channel, TRT 6, broadcasting only in Kurdish. How did such a momentous change occur?

Since 1934 Soviet citizens had had internal passports that recorded their ethnicity, ostensibly for purposes of positive discrimination. Dozens of ethnic groups indeed acquired autonomous territories and benefited from affirmative action policies. ${ }^{10}$ However, "passport ethnicity" also made possible the deportation of all ethnic Germans, Chechens, Crimean Tatars, and other ethnic groups, resulting in the decimation of their populations. ${ }^{11}$ Passport ethnicity was also used to discriminate against Jews in politics and employment. ${ }^{12}$ Attempts to remove ethnicity from the passport since the 1950s had failed. Even after the dissolution of the USSR, ethnicity was preserved in the internal passports of

\footnotetext{
${ }^{3}$ Göktürk, Gramling, and Kaes 2007, 154. For an examination of this law's origins, see Brubaker 1992.

${ }^{4}$ Halm 2006, sent to the author by Safter Çınar.

${ }^{5}$ Seferoğlu 1982.

${ }^{6}$ The usage of "mountain Turks" for Kurds dates back to the early republican period. Elphinston 1946, 101.

${ }^{7}$ Ünsal 2002.

${ }^{8}$ This thesis appeared in the "White Book" published by the Turkish General Staff after the 1980 military coup. Dündar 2009.

${ }^{9}$ Constitutional Court of Turkey 1983.

${ }^{10}$ Martin 2001.

${ }^{11}$ Nekrich 1978; Mukhina 2007.

${ }^{12}$ Zaslavsky and Luryi 1979.
} 
almost all the post-Soviet states. Yet in 1997 ethnicity was removed from the Russian internal passport. How did such a historic change occur?

In answering these questions, I will explain the dynamics of persistence and change in state policies regulating the relationship between ethnicity and nationality, which I conceptualize as "regimes of ethnicity." I will explain the causes of the momentous changes mentioned above and elaborate a theory of ethnic regime change.

\section{The Argument: Explaining Persistence and Change in REgIMES OF ETHNICITY}

Why do states' policies toward ethnic diversity often persist in very different national contexts and despite significant societal and political challenges aimed at changing them? What are the conditions for changing these policies, if change is even possible at all? I explain the persistence and change in policies related to ethnicity and nationality in Germany, the Soviet Union/post-Soviet Russia, and Turkey since the 1950s by reference to the presence or absence of three independent variables: counterelites, new discourse, and hegemonic majority. I argue that if "counterelites" representing constituencies with ethnically specific grievances come to power equipped with a "new discourse" on ethnicity and nationality and garner a "hegemonic majority," they can change state policies on ethnicity. These three factors are separately necessary and jointly sufficient for change. This finding is an improvement on the studies of nationalism and policy-making in the field of ethnic politics because it provides a parsimonious causal explanation, based on a detailed structured comparison of three important cases, of persistence and change in state policies on ethnicity.

These three cases of substantive importance are examined through a combination of Mill's method of agreement and his method of disagreement. The method of agreement is used across cases while the method of disagreement is used within cases. The analysis across cases is an example of "most different systems analysis," with Germany, the Soviet Union/Russia, and Turkey demonstrating significant differences in their dominant religious traditions, ethnic demography, population density, political systems, and levels of economic development. (See Table 1.) Moreover, state policies toward ethnic diversity are very different in these three countries. Therefore, the observation of an analogous process of transformation in state policies across these countries provides a robust confirmation of my argument that three elements are separately necessary and jointly sufficient for change. 
TABLE 1

Most Different Systems Analysis

\begin{tabular}{|c|c|c|c|}
\hline & Turkey & USSR E Russia & Germany \\
\hline $\begin{array}{l}\text { Dominant religious } \\
\text { tradition }\end{array}$ & Islam & $\begin{array}{l}\text { Eastern Christianity } \\
\text { (Orthodoxy) }\end{array}$ & $\begin{array}{l}\text { Western Christianity } \\
\text { (Catholic- } \\
\text { Protestant) }\end{array}$ \\
\hline Ethnic majority $^{a}$ & $76 \%$ & $\begin{array}{l}\text { 51\% (USSR); } \\
\text { 78\% (Russia) }\end{array}$ & $90 \%$ \\
\hline $\begin{array}{l}\text { Second largest ethnic } \\
\text { category }\end{array}$ & $15.7 \%$ & $\begin{array}{c}15.2 \% \text { in the USSR; } \\
3.8 \% \text { in Russia }\end{array}$ & $2.5 \%$ \\
\hline $\begin{array}{l}\text { Political system: } \\
\text { Freedom House } \\
\text { scores (2005) }\end{array}$ & 3.0 & $\begin{array}{l}5.5 \\
6.0(\mathrm{USSR}, 1980)\end{array}$ & 1.0 \\
\hline \multicolumn{4}{|l|}{$\begin{array}{l}\text { Level of economic } \\
\text { development: }\end{array}$} \\
\hline GDP per capita ${ }^{c}$ & $\$ 9,370$ & $\$ 10,030$ & $\$ 38,520$ \\
\hline Population density ${ }^{\mathrm{d}}$ & 85 & 9 & 230 \\
\hline Ethnic regimes & antiethnic & multiethnic & monoethnic \\
\hline $\begin{array}{l}\text { Process of ethnic } \\
\text { regime change }\end{array}$ & analogous & analogous & analogous \\
\hline
\end{tabular}

${ }^{a}$ The estimate for Turkey is based on KONDA's public opinion survey published in Milliyet (2007). Although 81.3 percent of the respondents identified as "Turkish," those administering the survey made adjustments based on language and family size that reduced ethnic Turks' share from 82 percent to 76 percent.

${ }^{\mathrm{b}}$ Second largest ethnic category is Kurds in Turkey, Ukrainians in the USSR, Tatars in post-Soviet Russia, and Turks in Germany.

${ }^{\mathrm{c}}$ EIU 2010, 104-6.

${ }^{\mathrm{d}}$ Economist 2001.

\section{Three Models of Political Community along Axes of Membership and Expression: Monoethnic, Multiethnic, And Antiethnic Regimes}

In order to better comprehend the nature of political contestation over state policies toward ethnicity, I coined the term "regimes of ethnicity" and categorized states as having monoethnic, multiethnic, and antiethnic regimes. Ethnicity regimes are defined along dimensions of "membership" and "expression." If a state seeks to restrict membership in the nation to one ethnic category through discriminatory immigration and naturalization policies, then it has a "monoethnic" regime and the expression dimension becomes irrelevant because ethnic diversity is minimized through the construction of a monoethnic citizenry. Germany before 1999 is a very good example approximating the ideal type of a state with a monoethnic regime-Japan, too, has a monoethnic 
regime. If a state accepts people from ethnically diverse backgrounds as citizens (membership) but discourages or even prohibits the legal, institutional, and public expression of ethnic diversity (expression), then it has an "antiethnic" regime. Turkey before 2004 is a very good example approximating the ideal type of a state with an antiethnic regime-France, too, has an antiethnic regime. If a state accepts people from ethnically diverse backgrounds as its citizens (membership) and allows, encourages, or even participates in the legal and institutional expression of ethnic diversity (expression), then it has a "multiethnic" regime. The Soviet Union and the post-Soviet Russian Federation are very good examples approximating the ideal type of a state with a multiethnic regime-Canada and India, too, have multiethnic regimes. "Regimes of ethnicity" denote the constellation of state policies and institutions related to ethnicity. This new conceptualization connects the study of nation-building to studies of ethnic diversity and citizenship, while providing a coherent typology of state policies on ethnicity that accommodates the full range of variation across cases.

The conceptual confusion in the study of ethnicity and the nationstate is reflected in the terminology used. A commonly used distinction between "ethnic" and "civic" nationalism dating back to Hans Kohn is problematic because the two terms are not mutually exclusive; "civic" is a vague, empty category; moreover, "ethnic" and "civic" are derived from different roots. ${ }^{13}$ Thus, the ethnic-civic dichotomy has been criticized by even some of its erstwhile proponents. ${ }^{14}$ Furthermore, although labeling "ethnic" nationalism as "Eastern" and nonethnic nationalisms as "Western" is derogatory of Eastern nations, it is a disturbingly common practice. ${ }^{15}$ If we seek to articulate a relationship between nationhood and ethnicity, the terms describing the universe of cases must have "ethnicity" as their reference point. Semantically, the route to precision is to derive adjectives from the root "ethnic" in differentiating notions of nationhood in their relationship to ethnicity. ${ }^{16}$ Logically, one can deduce three distinct ideal types: monoethnic, multiethnic, and antiethnic. ${ }^{17}$ One can arrive at these ideal types in two steps through the deductive test of "membership and expression." (See Figure 1.)

\footnotetext{
${ }^{13}$ Kohn 1944.

${ }^{14}$ Brubaker 2006.

${ }^{15}$ For many examples of using "ethnic" and "Eastern" nationalism interchangeably, see Smith 1986.

${ }^{16}$ In a similar vein, Steven Fish reclassifies political regimes as "monocracies" and "democracies" based on the ancient Greek suffix -cracy, meaning "to rule"; in Fish 2005, 20-27.

${ }^{17}$ One can split "multiethnic" into biethnic, triethnic, and so on, but these would be subsets of "multiethnic."
} 
Step 1: Membership

Limited to one ethnicity or not?
Step 2: Expression

Multiple ethnicities institutionalized or not?
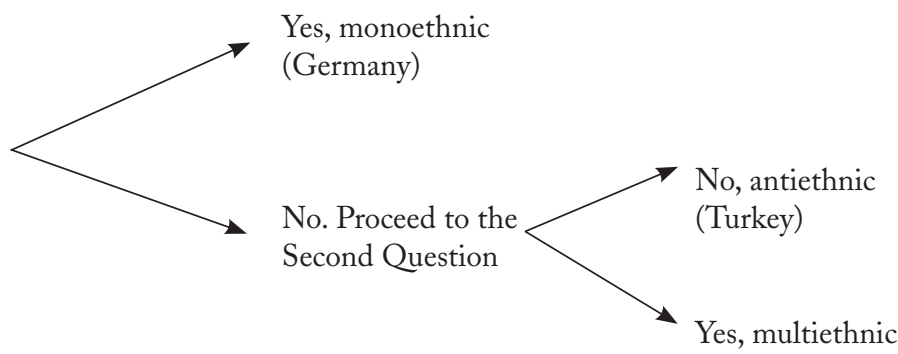

(USSR, Russia)

Figure 1

Deductive Test of “Membership and Expression”

Membership in the political community is the most important outward attribute of nationhood and has significant domestic implications. Membership is denominated by "citizenship." "Nationhood" is empirically constituted by the sum of citizens; therefore, restricting the acquisition of citizenship to one ethnic group would be the most direct symptom of a systematic effort to create a monoethnic nation.

Expression of ethnic differences becomes the key question only if multiple ethnic categories are allowed membership. In such cases, there can be two different models for relating ethnic background to national identity based on the legal-institutional expression of ethnic categories. If multiple ethnic categories are legally and institutionally recognized, then we have a multiethnic regime. If ethnic categories are not legally and institutionally recognized, then we have an antiethnic regime. (See Figure 2.)

\section{The Cluster of Policies and Institutions Symptomatic of Ethnicity Regimes: The Difficulty of Changing Even ONE POLICY}

Why do I use the term "regime" to describe state policies and institutions regarding ethnicity? I borrow the notion of a regime from EspingAndersen's understanding of welfare state regimes; when applied to state policies toward ethnicity, it indicates that "a complex of legal and organizational features are systematically interwoven." 18 State

\footnotetext{
${ }^{18}$ Esping-Andersen 1990, 2, italics added. Unlike the current author, Esping-Andersen, however, did not apply the concept of regimes to ethnic policies.
} 


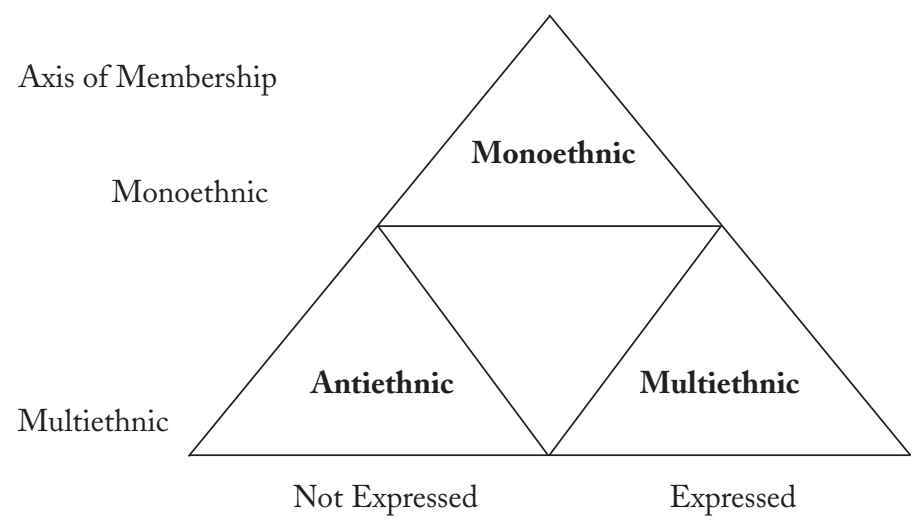

Axis of Expression

Figure 2

Three Ethnicity Regimes: Monoethnic, Multiethnic, And Antiethnic

policies on the ethnic background of subjects "are not linearly distributed, but clustered by regime-types." ${ }^{19}$ These policies are mutually reinforcing since they seek to maintain a particular and coherent relationship between ethnicity and nationality in each regime type. For example, Germany's citizenship policy before 2000 discouraged and prevented the naturalization of immigrants of nonethnic German origin residing in Germany, while its immigration policy encouraged ethnic Germans from Kazakhstan, Russia, Romania, and elsewhere to immigrate to Germany by guaranteeing them automatic citizenship. While the two policies did not need to align this way, they did so in order to preserve and re-create a monoethnic German nationhood.

The axes of membership and expression define an ethnicity regime, but what types of specific laws and regulations can be considered symptomatic of ethnicity regimes? The membership axis of ethnicity regimes can be captured by citizenship and immigration policy and by ethnic minority status. (1) Is citizenship restricted to only one ethnic group? (2) Is there ethnic-priority immigration? (3) Are there officially codified ethnic minorities, indicative therefore of the existence and titular status of an ethnic majority? The expression axis of ethnicity regimes is a constellation of four institutions and policies: (1) recognition of more than one ethnicity in the constitution, census, and key official documents, (2) ethnic federalism, (3) multiple official languages, and (4) ethnically based affirmative action.

${ }^{19}$ Esping-Andersen 1990, 26. 
How are these seven policies and institutions systematically interwoven? For example, in a monoethnic regime, ethnic-priority immigration is complemented by preferential naturalization for immigrants who share the titular ethnic background. This identifies them as the titular, state-bearing ethnic majority, and other ethnic categories are codified as ethnic minorities. Recognition of multiple ethnicities in the constitution, ethnic federalism, multiple official languages, and affirmative action are therefore not to be expected, because of the identification of the political community with one ethnicity. These seven policies together constitute a "regime." (See Table 2.) I focus on immigration and citizenship policies in Germany, demands for ethnic and linguistic rights in Turkey, and attempts to remove ethnicity from the internal passport in the Soviet Union and post-Soviet Russia, because these are the policies where political contestation over the relationship between ethnicity and nationality coalesced in each country, respectively. An explanation of persistence and change in these policies is substantively and theoretically crucial for understanding the dynamics of ethnic politics in these countries.

It is significant that even after more than half a century of attempts at reform, in each of the three countries that I examine significant change in policy occurred in only one of the seven policy areas that together constitute ethnicity regimes. Russia removed ethnicity from the internal passport, which is a movement away from a multiethnic regime toward one that is antiethnic, but other features of a multiethnic regime, such as ethnic federalism, remained in place. Turkey established new public television stations broadcasting exclusively in Kurdish and Arabic, which is a movement away from an antiethnic regime toward one that is multiethnic, but Turkey did not become an ethnofederal state, and other features of an antiethnic regime remained. Germany allowed the granting of citizenship to immigrants from different ethnic backgrounds under certain conditions, which is a movement away from a nonethnic regime toward one that is antiethnic, but ethnic Germans' privileged claim to citizenship and ethnic minority status remained. What does the limited nature of the change, limited in each case to one policy area, suggest about regimes of ethnicity?

First, after these changes were made, both Turkey and Russia became hybrid regimes falling along the continuum somewhere between antiethnic and multiethnic regimes. These instances of change and continuity demonstrate the extreme difficulty of changing state policies on ethnicity. Even the alignment of the proverbial stars - counterelites, new discourses, and hegemonic power-sufficed to change only one 
TABLE 2

Seven Symptoms of Ethnic Regime Type: Membership (1-3) \& EXPRESSION (4-7)

\begin{tabular}{lccc}
\hline \hline Policies/Ethnic Regime Type & Monoethnic & Multiethnic & Antiethnic \\
\hline 1. Ethnic priority in citizenship? & yes & no & no \\
2. Ethnic priority in immigration? & yes & no & no \\
3. Ethnic minority status? & yes & no & no \\
4. Multiple ethnic categories in the & no & yes & no \\
$\quad$ Constitution? In personal identification & & & \\
documents? & & & \\
5. Ethnic territorial autonomy? & no & yes & no \\
6. Multiple official languages? & no & yes & no \\
7. Ethnic affirmative action? & no & yes & no \\
\hline
\end{tabular}

significant state policy on ethnicity. And even the exceptional coincidence of three conditions for change in state policies on ethnicity might not be enough for a wholesale change in ethnic regime that encompasses all or most state policies on ethnicity.

Second, an entire ethnic regime change is very rare in modern history. Bolshevik counterelites, for example, armed with new socialist, Marxist-Leninist discourses on ethnicity and political community, assumed hegemonic power over their opponents after a very violent and protracted civil war and established the Soviet Union as a multiethnic federal state with affirmative action policies and passport ethnicity. ${ }^{20}$ A similar process occurred with Turkish nationalist counterelites who fought against the Ottoman sultan and the European occupation. They took power, armed with a new, Kemalist discourse on ethnicity and nationhood, with a hegemonic power against their opponents, and they established an antiethnic regime in Turkey based on assimilation. ${ }^{21}$ Such radical change occurs very rarely and is often preceded or accompanied by war and violence.

Third, the policy areas where change occurred (citizenship in Germany, passport ethnicity in Russia, and minority languages in Turkey) were also where the political struggles for changing the ethnicity regime coalesced in each country. There was never as much political struggle around the idea of abolishing the existing ethnofederal structure in Russia or establishing an ethnofederal structure in Turkey as there was around the issue of removing ethnicity from the internal passport in Russia and allowing broadcasting and publishing in ethnic minority

${ }^{20}$ Martin 2001.

${ }^{21}$ Zürcher 2004, esp. 133-205. 
languages in Turkey. In the Soviet case there is only one source suggesting that Yuri Andropov, who led the USSR for fifteen months in 1982-83, entertained the idea of abolishing ethnic federalism by reorganizing the Soviet Union as a nonethnic federal state. ${ }^{22}$ Even if one believes that Andropov indeed entertained such an idea, which I do, it is clear that such a singular episode pales in comparison with the repeated efforts to remove ethnicity from the internal passport. Likewise, although some Kurdish nationalists might have aspired to ethnofederalism in Turkey, ${ }^{23}$ the right to speak Kurdish, Zaza, and other minority languages has been a more widespread and persistent demand of much greater magnitude. The same is true of the demands for employment quotas for immigrants in Germany - the issue is incomparably less central to identity politics in Germany than is the issue of citizenship. ${ }^{24}$

\section{Modes of Accommodating Diversity in Different Regimes of Ethnicity: Assimilation, Segregation, and Consociation}

The antiethnic regime is premised on the malleability of collective identities: ethnic identities are supposed to give way to a national identity through a process of assimilation. In contrast, segregation, which entails the sustained separation of ethnic categories from the titular ethnic group, is the approach to ethnic diversity in a monoethnic regime. Finally, consociation is the approach of the state to ethnic diversity in a multiethnic regime. (See Figure 3.) Some argue that consociation and "multicultural citizenship" are morally and philosophically superior forms of political organization, as well as better for the survival of democracy. ${ }^{25} \mathrm{I}$ do not argue here for the moral, philosophical, or functional superiority of one ethnicity regime over others. All ethnicity regimes generate both resentment and support among different segments of the population. I now turn to the ethnicity regimes in Germany, the Soviet Union/post-Soviet Russia, and Turkey

Germany has been cited as the paradigmatic case of ethnic nationhood. ${ }^{26}$ The German citizenship law of 1913 crystallized the definition of the citizenry as a "community of descent." 27 "Before 1913 German

\footnotetext{
${ }^{22}$ In his posthumously published memoirs in a newspaper, Arkadii Volskii suggested that Andropov asked him to redraw the map of the USSR as a nonethnic federation with forty-one states, based on economic and functional needs; Volskii did this with the help of Evgenii Velikhov. Zavada and Kulikov 2006.

${ }^{23}$ For example, Güçlü 2007.

${ }^{24}$ Die Zeit 2006.

${ }^{25}$ Lijphart 1977; Kymlicka 1995.

${ }^{26}$ Kohn 1944; Brubaker 1992.

${ }^{27}$ Brubaker 1992.
} 


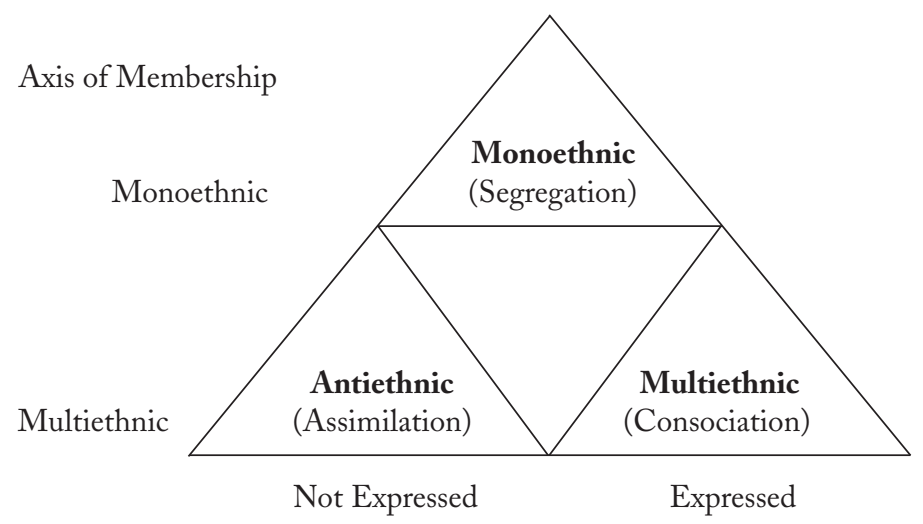

Axis of Expression

Figure 3

Modes of Governing Ethnic Diversity in the Three Ethnicity Regimes

citizenship law was internally inconsistent" because "it stood between two models - an older model of the citizenry as a territorial community, and a newer model of the citizenry as a community of descent, the former the product of the absolutist state, the latter of the emerging national state." ${ }^{28}$ The law of 1913 survived the Weimar Republic and the National Socialist dictatorship. Indeed, the citizenship law was preserved after 1945, and the new Bundesvertriebenengesetz (1953) and its reformulations, such as the Kriegsfolgenberechtigungsgesetz (1993), ensured that all ethnic Germans from Eastern Europe and Asia could immigrate to Germany and receive citizenship. ${ }^{29}$ There remained a few historical autochthonous nonethnic German populations in Germany: Danes and Frisians in Schleswig-Holstein, Sorbs in Brandenburg and Saxony, and Roma/Sinti. Together they constituted 0.3 percent of the population and were recognized as "ethnic minorities," to be distinguished from the "ethnic majority." (See Table 3.) In contrast, millions of nonethnic German residents of Germany, who were of immigrant origin, were not citizens. ${ }^{30}$ In terms of expression, Germany does not have multiple ethnic categories in the constitution, multiple official languages, ethnic federalism, or ethnically based affirmative action. Until the new citizenship law in 2000, Germany approximated the

\footnotetext{
${ }^{28}$ Brubaker 1992, 115.

${ }^{29}$ Bundesvertriebenengesetz 2009.

${ }^{30}$ Limiting ethnic minority status to these four ethnic categories sometimes creates the illusion that Germany is extremely homogenous. The following news article, for example, refers to the Sorbs as Germany's only ethnic minority. Deutsche Welle 2005.
} 
TABLE 3

Official Ethnic Minorities and the Largest Ethnic Groups in GERMANY (1997)

\begin{tabular}{lrcc}
\hline \hline Name & Population & Citizenship? & Official Minority Status? \\
\hline Danes & 50,000 & yes & yes \\
Frisians & 50,000 & yes & yes \\
Sorbs & 60,000 & yes & yes \\
Roma & 70,000 & yes & yes \\
Turks & $2,014,311$ & no & no \\
Yugoslavs & 662,691 & no & no \\
Italians & 586,089 & no & no \\
Greeks & 359,566 & no & no \\
Poles & 276,753 & no & no \\
Spanish & 132,283 & no & no \\
Portuguese & 125,131 & no & no \\
\hline
\end{tabular}

SouRCE: Compiled from Schmalz-Jacobsen and Hansen 1997. Schmalz-Jacobsen (FDP), who was the commissioner for foreigners' affairs in the CDU/FDP coalition government, remarkably titled her book Lexicon of Ethnic Minorities in Germany, although the overwhelming majority of those cataloged in the book are officially not ethnic minorities.

monoethnic regime type. Therefore, the immigrants' struggle for citizenship created the central political fault line with ethnic connotations in postwar Germany.

The Soviet Union (USSR) was the leading example of a multiethnic regime in the world. The extent of multiethnic recognition and institutionalization achieved in the USSR was unprecedented. Just as Germany stood for a particularly monoethnic formula for modern nationhood, the USSR was the model for a multiethnic political community. Membership was not ethnically restricted, and neither was there ethnic-priority immigration. There were no ethnic minorities, because all ethnicities together constituted the Soviet people.

Expression of ethnic differences was paramount. The USSR was structured as a multiethnic federation. The Soviet constitution mentioned dozens of ethnic categories, together constituting the USSR. There were 191 ethnic categories codified in the census of 1926 and recorded in internal passports issued to individual citizens. ${ }^{31}$ Dozens of ethnic territorial autonomies existed at different levels: union republics, autonomous republics, autonomous oblasts, krais, and okrugs. Ethnic groups received their own territories, flags, official languages, cultural institutions, and parliaments. Ethnically based affirmative action was used on so massive a scale- and so systematically for the first time in modern history - that a leading historian labeled the USSR

${ }^{31}$ Slezkine 1994; Hirsch 2005. 
an "Affirmative Action Empire." 32 "The unprecedented and unparalleled nature of the Soviet system of institutionalized multinationality is worth underscoring," another one commented. ${ }^{33}$ Recording ethnicity in internal passports enabled the state to systematically discriminate against many ethnic groups. "The internal passport system acted as a powerful instrument of social control but undermined the development of a common Soviet identity." ${ }^{34}$ The Russian Federation continued Soviet practices, including passport ethnicity, until 1997. The USSR and Russia approximate the ideal type of a multiethnic regime very well. (See Table 4.) Therefore, attempts to remove ethnicity from the internal passport created a central fault line in Soviet and post-Soviet Russian identity politics. ${ }^{35}$

Turkey maintained an antiethnic regime vis-à-vis ethnic diversity since the founding of the Republic in 1923. Its antiethnic regime had been more extreme and hence closer to the ideal type than even that of France, which is often considered the quintessential assimilationist antiethnic regime. Turkey does not have monoethnic citizenship laws or ethnic-priority immigration. On the contrary, Turkmenistan and Central Asia, where ethnic Turks are believed to originate, accounted for less than 1 percent of the immigration to Turkey in the twentieth century. ${ }^{36}$ Turkish citizenry is ethnically diverse, with estimates of Kurds and Alevis ${ }^{37}$ at around 15 percent each and with dozens of other ethnic categories. ${ }^{38}$ There are also up to three million Kurdish-speaking Alevis (approximately 4 percent of the population). ${ }^{39}$ Nonetheless, at least 76 percent of the population self-identifies as "Turkish." (See Table 1. $)^{40}$ There is no ethnic minority status and membership is not limited to one ethnicity.

In terms of the expression of ethnic diversity, Turkey does not have multiple ethnic categories in its constitution, does not record the ethnic

${ }^{32}$ Martin 2001.

${ }^{33}$ Brubaker 1996, 26.

${ }^{34}$ Sakwa, 1998, 252.

${ }^{35}$ Very few countries could approach the ideal type of a multiethnic regime as much as the Soviet Union did. Yugoslavia, India, and Canada come to mind in their far-reaching institutionalization of ethnic diversity.

${ }^{36}$ Dündar 2007; Ülker 2007.

${ }^{37}$ Alevis are an ethnoreligious group. Although they are usually defined by their religious-sectarian belief, a heterodox version of Shiite Islam, they also have a subjective belief in common descent and until recently maintained very high levels of endogamy. According to Max Weber, whose definition of ethnicity ("subjective belief in common descent") I adopt, Alevis definitely qualify as an ethnic group. See Yaman 2007a; Yaman 2007b; Yıldırım 2007; and Aktaş 2007.

${ }^{38}$ Dündar 1999.

${ }^{39}$ Immigration and Refugee Board of Canada 1995.

${ }^{40}$ Turkish self-identification might mean having Turkish citizenship (the official definition in the constitution), speaking Turkish, or being Muslim, without necessarily having an ethnic Turkish identity. 
TABle 4

Regimes of Ethnicity in Germany, Soviet Union / Russian Federation, AND TURKEY

\begin{tabular}{|c|c|c|c|}
\hline Policies/Cases & $\begin{array}{c}\text { Germany } \\
\text { (Monoethnic) }\end{array}$ & $\begin{array}{l}\text { USSR/Russia } \\
\text { (Multiethnic) }\end{array}$ & $\begin{array}{c}\text { Turkey } \\
\text { (Antiethnic) }\end{array}$ \\
\hline Ethnic priority in citizenship? & yes & no & no \\
\hline Ethnic priority in immigration? & yes & no & no \\
\hline Ethnic minority status? & yes & no & no \\
\hline $\begin{array}{l}\text { Multiple ethnic categories in the } \\
\text { Constitution? Census? }\end{array}$ & no & yes & no \\
\hline Ethnic territorial autonomy? & no & yes & no \\
\hline Multiple official languages? & no & yes & no \\
\hline Ethnic affirmative action? & no & yes & no \\
\hline
\end{tabular}

background of its subjects in official registers, and does not have multiple official languages, ethnic federalism, or ethnic affirmative action. Officially, that is, ethnicity is invisible. The constitution states in Article 66 that "every person who is tied to the Turkish state through citizenship is Turkish." The goal is the assimilation of people from many different ethnic backgrounds into a common national culture informed by Turkish language. Turkey approximates the ideal type of an antiethnic regime. Therefore, demands for the recognition of ethnic diversity created a central fault line within Turkish identity politics. (See Table 5.)

The consequences of state policies for ethnicity, ranging from affirmative action to ethnic territorial autonomy, are enormous, and these consequences provide a major motivation for seeking explanations of persistence and change in these policies. Nonetheless, my goal is not to assess the consequences of state policies. The causes of persistence and change in state policies constitute the missing link in the causal chain that connects otherwise disparate clusters of research and theory in social sciences. (See Figure 4.)

\section{Immigrant, Autochthone, or the Greatest EthniC Demographic Challenge?}

Some scholars may criticize the current endeavor, which compares Turks, Italians, Greeks, and other "immigrants" in Germany with "autochthonous" Tatars and Jews in Russia, and Kurds and Alevis in Turkey, since some consider ethnic diversity resulting from immigrant and 
TABLE 5

Challenges to the Status Quo and Issue-Areas of Contestation in ETHNic Politics

\begin{tabular}{llcll}
\hline \hline Country & Status Quo & Main Challenger & Fault Line & Issue-Area \\
\hline Germany & monoethnic & $\begin{array}{c}\text { antiethnic (e.g., } \\
\text { immigrants) }\end{array}$ & membership & citizenship \\
Turkey & antiethnic & $\begin{array}{c}\text { multiethnic (e.g., } \\
\text { Kurds, Alevis) }\end{array}$ & expression & minority languages \\
$\begin{array}{c}\text { USSR/ } \\
\text { Russia }\end{array}$ & multiethnic & $\begin{array}{c}\text { antiethnic (e.g., } \\
\text { Russians, Jews) }\end{array}$ & expression & passport ethnicity \\
\hline
\end{tabular}

autochthonous groups as being incomparable. This would be missing the entire point of this effort. When seen from the vantage point of the state, both immigrant and autochthonous minorities have a direct bearing on the nature of the nation. Therefore, "seeing like a state" from the perspective of a state- the ethnic diversity that is more relevant for the constitution of the nation might be immigrant in one context and autochthonous in another, depending mostly on ethnic demography. In Germany the four autochthonous official minorities have never been the primary challenge to the monoethnic conception of German nationhood. ${ }^{42}$ If anything, their symbolic "ethnic minority" status and demographic marginality reinforced the status quo. Ethnic

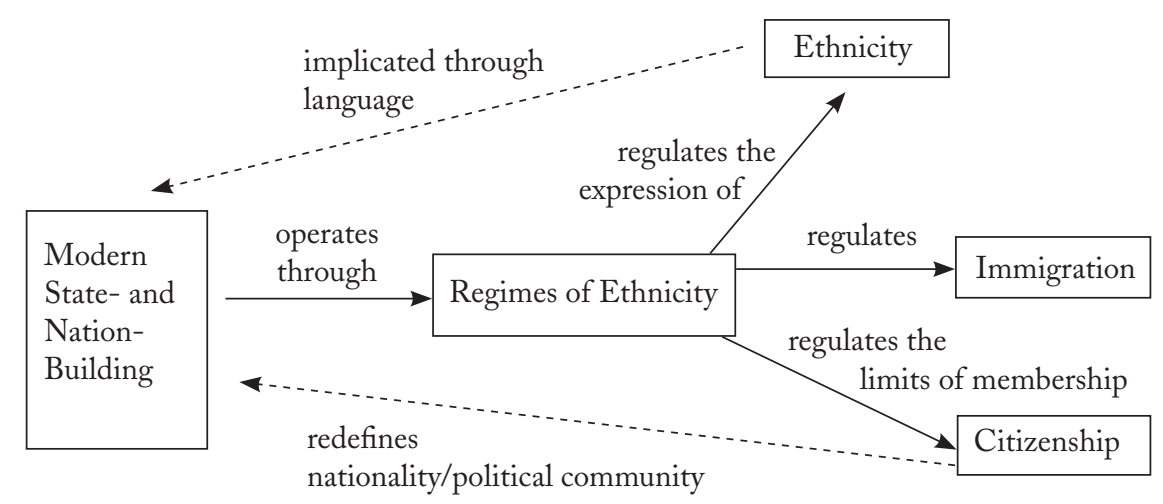

FIGURE 4

Linking Nation-Building, Ethnicity, Immigration, and Citizenship

${ }^{41}$ The allusion is to Scott 1999.

${ }^{42}$ Schurmann 2007. 
diversity resulting from the immigrants has been the primary challenge to the monoethnic conception of German nationhood. By contrast, in the Soviet/Russian and Turkish cases, autochthonous groups such as the Tatars and the Kurds were more numerous than the immigrants.

\section{The Key Policies of Contestation}

Each ethnic regime type activates a particular kind of political conflict. Therefore, ethnic regime type is a good predictor of the nature of political debates and contestation. Issues of membership, such as citizenship and immigration, would occupy center stage in monoethnic regimes, since people who do not share the titular ethnic background are excluded from membership. One would expect issues of expression to occupy the center stage in antiethnic regimes, where membership is ethnically diverse but institutional expression of ethnic diversity is not allowed. One would expect the ethnically specific allocations to occupy the center stage in multiethnic regimes, where ethnic diversity is already given institutional expression. For every ethnicity regime, change is possible in two directions, generating six possible transitions. (See Figure 5 and Table 5.)

\section{Alternative Explanations: State Collapse, Border Change, International Actors, Norms, and Global Waves}

Although state policies on ethnicity have not been previously conceptualized as regimes of ethnicity, a few works offered explanations for persistence and change in particular state policies on ethnicity. A prominent opinion in nationalism studies is expressed in Ernest Gellner's argument that ethnic minorities in nation-states have the option of changing their "culture" only by assimilating into the national culture or by changing the borders of the political unit by seceding and establishing their own nation-state. ${ }^{43}$ Critics can thus argue that state collapse or border change explains change in state policies toward ethnicity. I do not find this explanation convincing, however. First, one of my cases, Turkey, did not experience state collapse or border change. Second, although West Germany experienced border change by incorporating East Germany in 1990, this did not help but arguably hurt the prospects for reform. Indeed, reunification of West and East Germany reinforced the ethnic conception of nationhood, followed as it

\footnotetext{
${ }^{43}$ Gellner 1994, 108.
} 


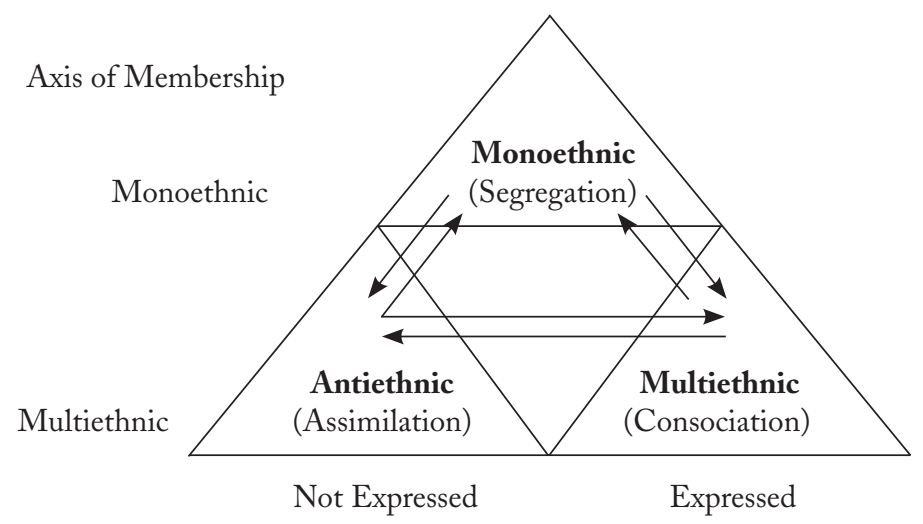

Axis of Expression

Figure 5

Six Possible Transitions between Ethnicity Regimes

was by a rapid rise in xenophobic attacks against immigrants; further, since East Germany was more than 99 percent ethnic German, reunification increased the demographic weight and political significance of ethnic Germans relative to immigrants. Post-Soviet Russia saw the most pronounced border changes of the cases under consideration and there border changes were likely to influence state policies on ethnicity. I agree that the dissolution of the USSR helped reformers seeking to remove ethnicity from the passport by removing the strongest political opponents of such a reform, the elites of the Union republics. Although Union republics were gone, however, twenty-one ethnic autonomous republics remained within Russia and were in general negatively disposed toward such a change. Moreover, coincident with the collapse of the USSR some of these ethnic autonomous republics, such as Tatarstan, Bashkortostan, and Chechnya, became as powerful and assertive vis-à-vis Moscow as some Union republics had been in the USSR. Finally and most importantly, that passport reform came about not in 1992 but in 1997 casts doubt on the assertion that state collapse and border change were the sole or primary reason for change.

Another set of explanations attributes change in state policies on ethnicity to external, international pressures, for example, from the European Union. I find this explanation, too, unconvincing. It is true that the EU takes a negative view of indicating ethnicity in individual passports: "the European Union has determined ... that the existence of such identity markers in ID cards is discriminatory and therefore 
incompatible with a European conception of human and civil rights." ${ }^{44}$ However, none of my interviewees in Russia referred to the EU or other international organizations in talking about the reform. Most importantly, the EU has very little if any power over Russia. In the case of Germany, the European Parliament had criticized Germany's restrictive, ethnic conception of citizenship already in the late 1970s, almost a quarter of a century before the citizenship reform, and yet even more restrictive anti-immigrant measures were adopted throughout the 1980s. The case of Turkey, where the EU argument is most prominent, suffers from a similar empirical and temporal mismatch: European institutions have condemned Turkey's treatment of its minorities in the harshest of terms since the 1980s. Since the end of military rule in 1983, fifteen democratically elected governments have came to power, all of which aspired to make Turkey part of the EEC and the EU, starting with Turgut Özal's first application for EEC membership in 1987. Yet it was in 2004 and 2008-9 that minority language reforms were implemented. Moreover, the greater reforms of 2008-9 occurred at a time when popular support for EU membership had dipped and fallen off the government's agenda. ${ }^{45}$

Some scholars argue that international norms and global waves exert influence on state policies and push them in a similar direction. Christian Joppke argued that there is an international trend in favor of abandoning ethnic-priority immigration schemes, adducing his evidence from eight liberal democratic states ${ }^{46}$ For Joppke, there was convergence on a "universalistic" position ${ }^{47}$ on immigration and citizenship in democratic states, which entailed a "retreat from multiculturalism" 48 and an agreement upon "civic integration" and "antidiscrimination" as the guiding principles of immigrant integration. ${ }^{49}$ In contrast, Checkel showed that "emerging $\mathrm{CE}$ [Council of Europe]-sponsored norms have had minimal constitutive effects in Germany to date," and that the diffusion of these norms through "elite learning" and "societal pressure," including "the liberal media, churches, trade unions, grassroots

${ }^{44}$ Arel 2001, 2.

${ }^{45}$ In 2007, only 50 percent of the people surveyed in Turkey said they would vote for Turkey's membership in the EU. This was the lowest percentage ever in this decade-long survey. Support dipped to a new historic low in 2009 with only 46 percent supporting EU membership. Aktürk 2007, 347; Ergin 2010.

${ }^{46}$ Joppke 2005, 49.

47 Joppke 2005, 91.

48 Joppke 2004.

${ }^{49}$ Joppke 2007. 
citizens' initiatives, and the commissioners for foreigners' affairs," has been limited. ${ }^{50}$

I find explanations based on the primacy of international norms and global waves unconvincing because my three cases do not exemplify a movement in the same direction. While Turkey moved away from an assimilationist position, Germany and Russia moved toward an assimilationist position. Even in these latter two cases, their movement was in opposite directions, since for Germany it was a "liberalization" to grant citizenship to immigrants' children born in Germany, while in Russia representatives of many ethnic groups protested against the removal of ethnicity from the passport. I do not observe a "convergence" in my three cases, let alone a convergence facilitated by the diffusion of an international norm. Furthermore, the wide variation still observed in the naturalization rates of immigrants and their ethnic, cultural, and religious freedoms in Western Europe casts doubt on arguments based on convergence to international norms. ${ }^{51}$

\section{A Theory of Ethnic Regime Change: Counterelites, New Discourse on Ethnicity and Nationality, and Political Hegemony Explain Change in Key Policies}

My argument about persistence and change in ethnicity regimes is based on the interdependence of three elements, as follows: counterelites, once armed with a new discourse on ethnicity and nationality and assuming hegemonic political power, can bring about change in the ethnicity regimes. These three elements are separately necessary and together sufficient for change. The change in the citizenship law in Germany, the removal of ethnicity from the internal passport in Russia, and the reform of minority languages in Turkey indicate a change in the ethnicity regime. There had been attempts to achieve these very changes since the 1950s, but these efforts had failed until a successful reform at the end of the century.

A counterelite is the political elite that is linked with, and representative of, constituents with ethnically specific grievances against the continuation of the ethnicity regime. Immigrants in Germany,

\footnotetext{
${ }^{50}$ Checkel 1999, 106, 99.

${ }^{51}$ Koopmans et al. 2005, 72: "It is sometimes posited that there is a general trend in Europe-or even worldwide - toward a convergence of conceptions of citizenship.... The other way to approach the issue is by looking at the range of variation among the countries. In this case, there are no signs of significant convergence.... On the cultural dimension, there are by contrast signs of increasing divergence."
} 
ethnolinguistic minorities in Turkey, and ethnic groups negatively affected by passport ethnicity in the USSR and Russia would be such constituencies. In the empirical analysis I focus on political parties in Germany and Turkey and political factions in the Soviet Union and Russia that had the support of such constituencies as the counterelites. My interviews and electoral analysis identify the political parties that had the support of constituencies with ethnically specific grievances, as well as the political elites who entertained changes in the ethnicity regime.

A new discourse on ethnicity and nationality is a comprehensive new formulation of the link between ethnicity and the nation that provides justification for specific changes in ethnicity regimes I examine in each country but goes beyond this change in its implications. It is the formulation of a new ideology of nationality. Multiculturalism represents one such big idea about ethnicity and the nation. Melting pot represents another. And brotherbood of nations (druzbba narodov), a Marxist formula, is yet another. My overview of new discourses on ethnicity, or lack thereof, is drawn from a review of parliamentary proceedings, party programs, and other key documents in Germany and Turkey, a review of Kommunist, the official journal of the Communist Party of the Soviet Union (CPSU), and publications of the Institute of Ethnology and Anthropology, writings of key personalities in ethnic politics, all supplemented with my interviews.

Political hegemony refers to disproportionate political power over the opposition. It is not enough for the counterelites to be in power, armed with a new idea about ethnicity and the nation; they also need to be disproportionately powerful vis-à-vis the opposition. Change in the regime of ethnicity does not come about with razor-thin majorities. I trace political hegemony by examining the parliamentary balance between the government and the opposition in Germany and Turkey and the president's power over his opponents in the Soviet/Russian cases.

Whenever these three factors were aligned, the ethnicity regime was changed. If any one of these factors was missing, change did not occur, and we witnessed continuity. Paul Pierson labels as "earthquakes" those processes whose outcomes unfold in a very short period of time, while their underlying causes are extremely slow moving, as evoked by the metaphor of earthquakes and seismic shifts. ${ }^{52}$ Ethnic regime changes certainly resemble political "earthquakes."

${ }^{52}$ Pierson 2003; Pierson 2004. 
My project follows a long tradition of comparative historical analysis in the social sciences, "defined by a concern with causal analysis, an emphasis on processes over time, and the use of systematic and contextualized comparison." ${ }^{53}$ The founders of modern social sciences, such as Smith, Tocqueville, and Marx, and some of the recent groundbreaking and award-winning research in the social sciences employed comparative historical analysis (CHA). ${ }^{54}$

While "comparative historical analysts are decidedly pluralistic in their use of overarching theories," there is an affinity with the approach of historical institutionalism in their work. ${ }^{55}$ Jack Goldstone lauds the virtues of CHA and notes that "[1]arge-N studies that seek to understand the causes of revolution (and nonrevolution) by ignoring the differences between the Soviet Union and Burundi, or between Cuba and Cambodia, and by treating all of these as equivalent 'cases,' seem bound to founder." ${ }^{56}$ This observation holds true for the study of ethnicity regimes. One cannot fruitfully pursue a variable-oriented large-N study - taking a snapshot of one variable's global distribution at one point in time, assuming equivalence between all the cases, ignoring their context-and derive a causal inference that explains the variation or change over time in ethnicity regimes.

The structure of my argument is what Gary Goertz labeled as the "Necessary and Sufficient Condition Concept Structure," ${ }^{57}$ with three necessary conditions generating eight possible configurations. Therefore, my argument is entirely falsifiable, and the following seven configurations, if they hold, would falsify my theory of ethnic regime change. (See Table 6.)

In the dichotomy between "variable-oriented" and "case-oriented" research, where "there is an inverse relation between the number of cases and the number of aspects of cases (or 'variables') that researchers study," one can strengthen the causal inference by making multiple observations based on temporal subsections of each case. ${ }^{58}$ While this study focuses on three countries, each country in the analysis is subdivided into periods defined by the different governments in power, and these usually correspond to different configurations of variables. These periods are distinctive enough to be considered as different "cases."

${ }^{53}$ Mahoney and Rueschemeyer 2003, 6 .

${ }^{54}$ Mahoney and Rueschemeyer 2003, 2-3. Refer to the books cited here for examples of recent social science research employing CHA.

${ }^{55}$ Mahoney and Rueschemeyer 2003, 21, 15.

${ }^{56}$ Goldstone 2003, 43.

${ }^{57}$ Goertz 2006, 40.

${ }^{58}$ Ragin 2000, 23. 
TABLE 6

Seven Configurations That Would Falsify the Theory of Ethnic Regime Change Presented in This Article

\begin{tabular}{cccc}
\hline \hline Counterelite & New Discourse & Political Hegemony & $\begin{array}{c}\text { Ethnic Regime } \\
\text { Change }\end{array}$ \\
\hline+ & - & - & + \\
- & + & - & + \\
- & - & + & + \\
+ & + & - & + \\
- & + & + & + \\
+ & - & + & + \\
- & - & - & + \\
\hline
\end{tabular}

Why These Elements Are Separately Necessary and Together Sufficient for Change: The Significance OF INTERESTS, IDEAS, AND CONSTRAINTS

Counterelites provide the actors with the motivation, interests, and preferences necessary to initiate a reform on behalf of their constituencies who have grievances against the status quo. The new discourse on ethnicity and nationality performs multiple indispensable functions. It provides the cognitive frame and ideas necessary for action and a new vision of the nation with which to counter the defenders of the status quo in debates and propaganda. It also links the ethnic grievances of an otherwise minority/lobby group to a nationwide ideology. Finally, political hegemony is necessary to overcome institutional inertia manifest in the bureaucracy, the military and the security apparatus, the intelligentsia and academia, and other nonpolitical actors that have an interest in the reproduction of the status quo. Not only does a potential reformer need to battle his/her political opponents in the parliament, but he/she also has to overcome the resistance of other key institutions with significant power. Therefore, not a razor-thin majority but a wide margin of power and political hegemony is necessary for bringing about ethnic regime change.

Is this explanation significant, or does it border on tautology by arguing no more than that policy change occurs when a group that wants it to happen appears and gains the power to do it? I argue to the contrary, that the argument presented here is counterintuitive, significant, and even surprising. I suggest that "being in power" (that is, being in government) and wanting to change state policies on ethnicity are not enough to change them. This is demonstrated more than once in different case studies. The SPD-FDP coalition government that ruled Germany for 
thirteen years (1969-82) had every reason to change the citizenship law or at least rapidly naturalize immigrants but was successfully prevented from doing so by the CDU/CSU opposition and the then-dominant discourse. ${ }^{59}$ The SHP-DYP coalition government in Turkey (1991-95) even had it in its official Coalition Protocol (1991) that publishing, broadcasting, and education in the native languages of citizens (that is, Kurdish and other minority languages) would be allowed, and yet these promises were not realized. ${ }^{60}$ Being in government with a simple majority in parliament was not enough. In Turkey successful change came under AKP, which controlled two-thirds of the parliament (365 of 550) in Turkey, and the new German citizenship law also passed with a twoto-one vote in favor (365 to 182) in the Bundestag. These are significant findings that redefine what it means to "be capable" of changing state policies on ethnicity.

A similarly counterintuitive outcome with an element of surprise exists in the case of a government that commands an overwhelming majority in the parliament-in part the result of the support given to it by constituencies with ethnically specific grievances-yet does not change any of the state policies on ethnicity. A striking example of this phenomenon is the Democratic Party (DP) in Turkey, which won nine of the ten Kurdish-majority provinces in the 1954 elections and gained 93 percent of the seats in parliament (502 of 541), yet did not change state policies on ethnicity. ${ }^{61}$ I suggest that the reason was the lack of a new discourse on ethnicity and nationality within the DP. Kurdish or other ethnolinguistic diversity was not even mentioned by the DP in any programs of the five governments they formed between 1950 and 1960 . Surely this testifies to DP's full acceptance of the logic of assimilation and the official discourse that "there are no Kurds in Turkey." This surprising and counterintuitive outcome is neither banal nor tautological.

The parsimonious nature of the explanatory framework allows other scholars to test the argument by seeking cases where state policies on ethnicity changed without the three conditions I hold to be separately necessary and together sufficient for change. ${ }^{62}$ Conversely, there cannot

\footnotetext{
${ }^{59}$ Heinz Kühn, the government's federal commissioner of foreigners, openly demanded the rapid naturalization of foreigners in his famous report in 1979.

${ }^{60}$ See твмм 1991, Appendix 3.

${ }^{61}$ The Kurdish-majority provinces that DP won were Ağrı, Bingöl, Bitlis, Diyarbakır, Hakkari, Mardin, Muş, Siirt, and Van. The only Kurdish-majority province DP lost was Tunceli. The list of Kurdish-majority provinces is based on Mutlu 1996.

${ }^{62} \mathrm{~A}$ similar process of knowledge accumulation occurred in the study of social revolutions, starting with the works of Barrington Moore and Theda Skocpol. Skocpol's argument that social revolutions in France, Russia, and China happened because of the coincidence of peasant rebellions and state breakdown precipitated by relative decline in international military competition was parsimonious enough to
} 
be, and are no, cases where elites are electorally and ideologically motivated, willing to change state policies on ethnicity, and armed with a hegemonic majority in the political arena, and yet do not change state policies.

\section{Overview of Failed and Successful Challenges to the Ethnicity Regimes in Germany, the Soviet Union/Post- Soviet Russia, And Turkey since The 1950s}

\section{GERMANY, 1949-2005}

The first governments of the newly constituted Federal Republic of Germany after the Second World War were the Christian Democratic (CDU/CSU) governments led by Konrad Adenauer until 1966. CDU/ CSU cannot be considered a counterelite, because it did not represent constituencies with grievances against the monoethnic regime. On the contrary, CDU/CSU represented conservative constituencies whose views on ethnic cohesion were rooted in the citizenship law of 1913. These constituencies included the ethnic German expellees from Eastern $\mathrm{Eu}-$ rope and the USSR, whose inclusion in the German nation was based on their ethnicity. ${ }^{63}$ However, by signing the "foreign worker recruitment treaties" starting with Italy in 1955, and continuing with Spain, Greece, Turkey, and others, the CDU/CSU government facilitated the influx of a nonethnic German population to Germany. ${ }^{64}$ Since workers were linked to the SPD through the labor unions, it was the SPD that became the counterelite. Immigrant workers were highly unionized, very active, and flexing their political muscle in workers' council (Betriebsrat) elections where they could vote..$^{65}$

THE SPD-FDP coalition government governed Germany for thirteen years (1969-82). This represents the period when a counterelite was in power, but without a new idea about ethnicity and nationality.

be tested in the case of future revolutions. Moore 1966; Skocpol 1979; Keddie 1995; Goldstone 2003.

${ }^{63}$ Interview with a scholar of ethnic German Aussiedler descent from Poland.

${ }^{64}$ For the ethnic tensions between immigrant workers and Germans, and the reception and reaction to ethnic diversification in politics and the media from the 1950s to the 1970s, see Schönwälder 2001; and Schönwälder 2007.

${ }_{65}$ Alpbek 2007; Baran 2007; Çınar 2007; Keskin 2007; Kolat 2007. Hakkı Keskin was an immigrant leader, formerly SPD politician, member of the Bundestag from the Left Party (2005-9). Safter Çınar is a former president of Türkische Gemeinde in Deutschland (TGD) and is currently the commissioner of migration in Deutscher Gewerkschaftsbund (DGB). Kenan Kolat is the current president of TGD. Riza Baran was the president of the Friedrichshain-Kreuzberg local council, a KurdishGerman politician, in the Green Party. Mehmet Alpbek is a representative of Migrationsrat. 
Between 1969 and 1971 the SPD-FDP government had a majority not only in Bundestag but also in the Bundesrat; that is, it enjoyed a hegemonic majority. ${ }^{66}$ Immigrants were overwhelmingly positioned on the left and linked to the SPD through labor unions throughout this period and beyond. ${ }^{67}$ Why would the SPD not seek to naturalize these immigrant workers and their families, who would most likely then vote for the party? The answer lies in their inability to provide a new discourse about German nationhood that could justify reforming the citizenship law.

The Bund Länder Commission of 1977 revamped the monoethnic definition of German nationhood by declaring that "Germany is not a country of immigration." ${ }^{8}$ This became a new catchphrase and reference point in defending the status quo, leaving immigrant activists to struggle against this mantra for the next two decades. ${ }^{69}$ Although the debates in the Bundestag during this period show a different emphasis in the SPD-FDP government and the CDU/CSU opposition, with the former taking a sympathetic position vis-à-vis immigrants and asylum seekers, both sides pledged not to turn Germany into "a country of immigration" (Einwanderungsland) and not to naturalize foreigners (Ausländer) living in Germany. ${ }^{70}$ Both parties initiated proposals to restrict family reunification, the only remaining means of de facto immigration after the 1973 moratorium on foreign labor recruitment. ${ }^{71}$

Against this background, the recommendations and proposals of Heinz Kühn, the first commissioner of foreigners' affairs of the government, fell on deaf ears in 1979. Kühn recommended naturalizing immigrant workers and their families and embarking on a comprehensive project for integrating them into German society through educational and cultural programs. ${ }^{72} \mathrm{He}$ recognized that the so-called guest workers were in fact immigrants. However, the SPD-FDP elite's commitment to the discourse of status quo, manifest in the recommendations of the

${ }^{66}$ Wehling 1989, 59.

${ }^{67}$ Çinar 2007; Kolat 2007.

68 "Vorschläge der Bund-Länder-Kommission zur Fortentwicklung einer umfassenden Konzeption der Ausländerbeschäftigungspolitik." Summarized in Herbert 2003, 245.

${ }^{69}$ Çinar 2007; Kolat 2007.

${ }^{70}$ Among many examples, see Dr. Penner (SPD) and Dr. Wendig (FDP), confirming their belief that Germany is not a country of immigration, in Bundestag 1980, 18530-18533.

${ }^{71}$ Çınar 2007: "While Kühn was speaking about opening new opportunities, Schmidt government made family reunion more difficult by lowering the age of children (qualified for family reunion) from 18 to 16 in 1981. (The government passed new laws stipulating that) you need to be married in Turkey three years before in order to be able to bring your spouse (to Germany). The constitutional court reversed this law."

${ }^{72}$ Kühn 1979. 
BLK and encapsulated in the idea that "Germany is not a country of immigration," made them unable to follow through on citizenship and naturalization reform in accordance with Kühn's recommendations.

The CDU/CSU-FDP coalition government (1982-98), while it witnessed a conservative government's spectacular attempts to reinforce the monoethnic regime, also provided a gestation period when new ideas about ethnicity and nationhood developed in opposition. Upon assuming the chancellorship, Helmut Kohl announced that cutting the number of "foreigners" by half would be one of the three major goals of his administration. To this end, his government offered 10,500 DM to any foreigner/immigrant who left Germany. Even though this policy succeeded in sending away only about three hundred thousand immigrants, or about 7 percent of the immigrant population at the time, it was hailed as a success by the government. ${ }^{73}$ Further to the right of CDU/CSU, a group of German scholars expressed their concern that "[m]any Germans already feel foreign in their own neighborhoods, workplaces, and homeland in general." ${ }^{74}$ Liselotte Funcke, the commissioner of foreigners' affairs from the FDP, resigned in June 1991 in opposition to CDU/CSU's restrictive policies against foreigners. ${ }^{75}$

In stark contrast, the newly emergent Green Party decisively broke with the prevailing discourse, denounced Germany's treatment of immigrants as being reminiscent of South African apartheid and a legacy of Nazi dictatorship in parliament, and conceptualized ethnolinguistic and cultural diversity as a foundation of democratic pluralism within a discourse of multiculturalism. ${ }^{76}$ Also in the 1980s immigrant organizations publicly demanded civil rights, including citizenship. ${ }^{77}$ In 1986

\footnotetext{
${ }^{73}$ Minister of Labor Blüm wrote to Chancellor Kohl that about three hundred thousand foreigners were sent back to their countries of origin, and, as such, an important goal of the government had been fulfilled. Herbert 2003, 255.

${ }^{74}$ Bambeck et al. 1982; English translation in Göktürk, Gramling, and Kaes 2003, 111. See also Hennessy 1982, 637. The signatories of the Heidelberg Manifesto were Prof. Dr. Bambeck (Frankfurt), Prof. Dr. R. Fricke (Karlsruhe), Prof. Dr. W. Haverbeck (Vlotho), Prof. Dr. J. Illies (Schlitz), Prof. Dr. P. Manns (Mainz), Prof. Dr. H. Rasch (Bad Soden), Prof. Dr. W. Rutz (Bochum), Prof. Dr. Th. Schm.-K. (Bochum), Prof. Dr. K. Schürmann (Mainz), Prof. Dr. F. Siebert (Mainz), and Prof. Dr. G. Stadtmüller (Munich).

${ }^{75}$ Funcke 1991. Funcke also emphasized that the xenophobia in the five new (East) German states is sending out alarm signals. This is another indication that the border change exemplified by German (re)unification did not help but possibly hurt the prospects of ethnic regime change.

${ }^{76}$ Speech of Joschka Fischer (Greens) in Bundestag 1984.

${ }^{77}$ In 1981 a group of immigrant activists of Turkish origin, established the Working Group for Equal Rights and Integration in Berlin and published a pamphlet provocatively titled "Foreigners' Views on the Policies on Foreigners." IGI 1981. See also Der Tagesspiel 1981. After the murder of a young Turk, Ramazan Avc1, on December 25, 1985, by skinheads in Hamburg, a group of Turkish activists led by Hakkı Keskin established the Union of Turkish Immigrants (Bündnis türkische Einwanderer) in 1986, deliberately defining themselves as "immigrants" rather than "guest workers," hence contributing to a new discourse. Keskin 2007.
} 
immigrant workers organized under the German Trade Union (DGB) succeeded in passing a resolution declaring Germany a "country of immigration." 78 The civil rights movement of immigrants had begun in earnest. People of immigrant origins assumed political posts, mostly in the Green Party. ${ }^{79}$ The SPD was gradually pressured from below by foreign workers to adopt the position that Germany is a country of immigration. Mostly left-liberal German scholars and intellectuals, exemplified in the Rat für Migration, lobbied for easing of naturalization and granting citizenship to immigrants. ${ }^{80}$ SPD's approach to ethnic diversity distinguished it from that of the Greens, by maintaining that only active foreigners who had contributed to the German economy for a long time and demonstrated significant progress in integration/ assimilation processes should be considered potential members of the political community, hence attributing a merit-based distinction to resident foreigners that asylum seekers did not deserve. ${ }^{81}$

A counterelite consisting of Greens and some Social Democrats, armed with new ideas on ethnicity and nationality, was formed in opposition throughout the 1980s and the 1990s. This historic bloc assumed power in 1998 with a clear majority. (See Table 7.) Moreover, both the FDP and the PDS, two of the three parties in the opposition, favored extending citizenship to most immigrants, which gave the SPDGreen government a hegemonic majority for changing the citizenship law. However, within the government, the SPD had a more assimilationist orientation, whereas the Greens were divided between multiculturalist and assimilationist camps. The first draft law on citizenship in 1998 reflected this compromise. ${ }^{82}$ The anti-immigrant signature

${ }^{78}$ Çınar 2007.

79 Ceyhun 2007; Mutlu 2007; Öney 2007; Holzberger 2007; Mesghena 2007. Ozan Ceyhun, currently SPD, formerly Green politician, member of the European Parliament (1998-2004); Özcan Mutlu and Bilkay Öney, members of the house of representatives of Berlin, Green Party; Mark Holzberger, Green Party adviser for migration, refugees, and integration policies in the Bundestag; Mekonnen Mesghena, senior officer, Migration Policy and Intercultural Management, Heinrich Böll Foundation.

${ }^{80}$ Leggewie 2007; Schiffauer 2007; Münz 2007; Şenocak 2007; Brenner 2007. Claus Leggewie, Werner Schiffauer, and Rainer Münz were members of the Rat für Migration. Zafer Şenocak is a prominent Turkish-German novelist and public intellectual. Michael Brenner is a professor of Jewish history at the University of Munich. See, for example, Leggewie 1990; and Leggewie and Şenocak 1993.

${ }^{81}$ For example, Thomas Schröer's (SPD-Müllheim) speech in the Bundestag 1990, 15028.

${ }^{82}$ Beck 2007; Bürsch 2007; Laurischk 2007; John 2007; Demirbüken-Wegner 2007; Klepp 2007. Marieluise Beck, member of the Bundestag (Greens, 1983-85; 1987-90; 1994-present) and the federal commissioner of foreigners' affairs (1998-2005); Michael Bürsch, member of the Bundestag (SPD, 1997-present), speaker of the SPD Working Group on Migration and Integration; Sibylle Laurischk, member of the Bundestag (FDP, 2002-present); Barbara John, CDU politician, commissioner of foreigners' affairs of the Berlin Senate (1982-2003); Emine Demirbüken-Wegner, cDU politician, member of the house of representatives of Berlin; Volker Klepp, rapporteur for the Federal Office of Foreigners' Affairs under Cornelia Schmalz-Jacobsen (FDP) and Marieluise Beck (Green); and previously cited interviews. 
TABLE 7

Unsuccessful and Successful Attempts to Change the Monoethnic Regime in Germany, 1949-2005

\begin{tabular}{lcccc}
\hline \hline Germany & Counterelite? & New Discourse? & Hegemony? & Change? \\
\hline CDU-FDP, 1949-66 & no & no & yes & no \\
CDU-SPD, 1966-69 & yes & no & no & no \\
SPD-FDP, 1969-72 & yes & no & yes & no \\
SPD-FDP, 1972-82 & yes & no & no & no \\
CDU-FDP, 1982-98 & no & no & yes & no \\
SPD-Green, 1998-2005 & yes & yes & yes & yes \\
\hline
\end{tabular}

campaign and the loss of the elections in Hessen in 1999 forced these differences into the open and led to the redrafting of the new citizenship law strictly around the idea of assimilation. The new citizenship law passed in the Bundestag on May 7, 1999, with 365 members voting in favor, 182 voting against, and 39 abstaining. ${ }^{83}$ On July 27, 2002, Minister of Interior Otto Schily (SPD) famously declared that the best form of integration is assimilation, and since then assimilationism has been the hegemonic reformist position. The SPD, the FDP, most Greens, and some Christian Democrats together constructed a hegemonic majority around the assimilationist position. Monoethnicist CSU and some members of the CDU who wanted to defend the status quo were sidelined, along with the multiculturalist members of the Greens and the Left Party (formerly PDS). Unsurprisingly, naturalized nonethnic German immigrants voted overwhelmingly for the SPD and the Greens. ${ }^{84}$

\section{The Soviet Union and the Russian Federation, 1953-97}

In the Soviet Union and post-Soviet Russia, recording ethnicity on internal passports benefited some ethnic groups but harmed others. Those ethnic groups that had ethnic autonomous territories and benefited from affirmative action policies, such as Kazakhs, Kyrgyz, Tatars, Bashkirs, by and large favored registering ethnicity on the internal passport and opposed removing it. Those ethnic groups that did not have ethnic autonomous territories and were harmed by discrimination due to their ethnicity - such as Jews and Germans, as well as ethnic Russians who lived in ethnic autonomous territories and who felt that affirmative action policies benefited minorities - by and large favored the removal of ethnicity from the internal passport.

${ }^{83}$ Bundestag 1999, 3466.

${ }^{84}$ Wüst 2004, 341-59. 
Following Stalin's death in 1953, Khrushchev repudiated many Stalinist policies, most famously in his "Secret Speech" in 1956. With his language reform of $1958,{ }^{85}$ increased antireligious campaigns and the creation of new rituals ${ }^{86} \mathrm{Virgin}$ Lands project, and administrative initiatives such as "cadre rotation" and "sovnarkhozy" reform, ${ }^{87}$ Khrushchev aimed at linguistic, (anti)religious, administrative, and economic homogenization in order to create a supraethnic Soviet community. Based on some of his actions, such as the amnesty of most ethnic groups deported by Stalin, Khrushchev could be said to have been more representative of those ethnic groups that suffered from the Stalinist policies, especially the use of passport ethnicity as a discriminatory tool.

Khrushchev entertained the idea of removing ethnicity from the internal passport and replacing it with "Soviet." ${ }^{8}$ Working groups were established to discuss this possibility ${ }^{89}$ However, the anticipation of opposition from the Union republics led them to conclude that the time was "not right" for this reform..$^{90}$ Given the Stalinist ideological establishment built around the idea of passport ethnicity and institutionalized multinationality, Khrushchev's initiative was weak on the ideological front. He also did not wield hegemonic political power over the opponents, the titular elites in the Union republics. The idea of a Soviet People/Nation (sovetskii narod) was popularized in official publications as a supraethnic identity, especially after Khrushchev's speech to the 22nd Party Congress in 1961, where he declared the Soviet nation to be a "new historic community of people" formed through socialism. ${ }^{91}$ He was ousted a few years later, in 1964.

The discourse of sovetskii narod gestated for decades, reaching the peak of its popularity in the late 1970s and early 1980s. "During the preparation of the new passport reform [of 1974] an even more radical proposition was considered: the complete deletion of registration of nationality from the internal passport." ${ }^{33}$ "Liberals" are often identified as supporters of reform at this time. ${ }^{94}$ Moreover, "many representatives

${ }^{85}$ Bilinsky 1962, 138-57.

${ }^{86}$ Sadomskaya 1990, 94-113.

${ }^{87}$ Miller 1977, 3-36; Cutler 1980, 15-35.

${ }^{88}$ Burlatskii 2007. Fyodor Burlatskii was one of Khrushchev's advisers and speechwriters.

${ }^{89}$ Burlatskii 2007.

${ }^{90}$ Burlatskii 2007.

${ }^{91}$ References to sovetskii narod in Khrushchev's speeches can be found, for example, in KPss 1961, $1 / 4 / 89,26,28,29,222$, and $1 / 4 / 90,14,82,90,96$, and $1 / 4 / 91,15,142$, and $1 / 4 / 92,33$.

${ }_{92}$ Among many examples in the journal Kommunist, the official journal of the CPSU, see Rogachev and Sverdlin 1963; Editorial 1965; Editorial 1966; Editorial 1972; Editorial 1976; Ignitkhanian 1971; Iovchuk 1973; Zimanas 1965; Kommunist 1977.

${ }^{93}$ Zaslavsky and Luryi 1979, 149.

${ }^{94}$ Khrushchev 2009. Sergei Khrushchev is the son of Nikita Khrushchev. 
of Jewish and German national groups who see in the passport system the last impediment to their assimilation" are also cited as supporters of reform. ${ }^{95}$ However, this attempt at removing ethnicity from the passport under Brezhnev also failed.

As neither Khrushchev's nor Brezhnev's government openly declared an intention to remove ethnicity from the passport, their efforts take on the appearance of phantom attempts. This is not at all surprising, since Soviet governments could never declare that they would remove ethnicity from the passport without being absolutely sure that they could do it. In conformity with the principle of "democratic centralism," the Central Committee of the CPSU would take up these matters in secret meetings, where differences could be aired. In public, however, only one view would be presented and that would be defended unanimously. This is a crucial difference between what one observes in the nondemocratic, authoritarian one-party regime of the USSR and what one sees in post-Soviet Russia, Germany, and Turkey.

A structural problem that made the central government's attempts at reform an uphill battle was the diffusion of power from the center to the Union republics. ${ }^{96}$ After Stalin, the titular leaderships in the Union republics gradually gained power vis-à-vis the center, which made achieving hegemonic power behind the project of abolishing passport ethnicity less likely in the 1970s than it had been in the 1960s. (See Table 8.) The dissolution of the USSR played a role in improving the chances of passport reform in Russia by removing the Union republics from the domestic political calculus; but the collapse also strengthened ethnic republics within Russia. ${ }^{97}$

${ }^{95}$ Zaslavsky and Luryi 1979, 149-50.

${ }^{96}$ The interviews for the Soviet and Russian cases included Tishkov 2007; Kuvaldin 2007; Naumkin 2007; Drobizheva 2007; Arutyunov 2007; Guboglo 2007; Shnirelman 2007; Pain 2007; Lipman 2007; Miller 2007. Valery Tishkov, former minister of nationalities, currently the director of the Institute of Ethnology and Anthropology (IEA) and a member of the Public Chamber; Viktor Kuvaldin, speechwriter for Mikhail Gorbachev; Vitaly Naumkin, president of International Center for Strategic and Political Studies; Leokadia Drobizheva, head of the Institute of Sociology; Sergei Arutyunov, Mihail Guboglo, and Viktor Shnirelman, members of IEA; Emil Pain, adviser to President Yeltsin; Masha Lipman, Carnegie Moscow Center; Alexei Miller, scholar of Russian nationalism.

${ }^{97}$ Moreover, the collapse was interpreted in part as being a result of the ethnofederal, multiethnic structure of the state and this interpretation stigmatized expressions of multiethnic nationhood, which included passport ethnicity. Multiethnic nationhood began to be perceived as a liability. This is a radical contrast to the Bolshevik elites' interpretation of the Habsburg and Ottoman collapse during World War I. Bolsheviks thought that the Habsburg and Ottoman collapse demonstrated the inevitability of the emergence of modern nations; and in order to fight fire with fire, they decided to overcompensate ethnic communities within the former Russian Empire with territorial autonomy, official languages, affirmative action, national flags, and the like, in order to keep the territorial integrity of this multiethnic landscape within a socialist state structure, a program that succeeded for another seven decades. Martin 2001; Hirsch 2005. 
TABLE 8

Average Time in Office of Native Party Secretaries in ETHNIC REPUBLICS

\begin{tabular}{lccccc}
\hline \hline & \multicolumn{5}{c}{ In Office in the Year } \\
& 1955 & 1960 & 1965 & 1970 & 1975 \\
\hline $\begin{array}{l}\text { Average number of years } \\
\text { already in office }\end{array}$ & 4.0 & 5.0 & 6.6 & 8.2 & 9.6 \\
\hline
\end{tabular}

SOURCE: Adapted from Miller 1977, 21, Table 4.

a "Already in office" refers to the length of time that the native party secretaries have already been in office; for example, in 1960 the average party secretary in ethnic republics has been in office for 5.0 years, that is, since 1955 .

A counterelite came to power under Yeltsin's presidency, representing constituencies with ethnically specific grievances against passport ethnicity, including Russian Jews. Jews were disproportionately represented in Yeltsin's governments, such that up to a dozen people of Jewish origin served in his cabinets, and Jewish citizens overwhelmingly supported Yeltsin in various elections. ${ }^{98}$ By contrast, in 1984, only one out of one hundred leading Soviet officials was of Jewish origin. ${ }^{99}$ Of the Jewish members of Yeltsin's governments, several had responsibilities directly linked to the role of ethnicity in state-society relations, including Yevgeny Sapiro, minister of nationalities, and Emil Pain, an adviser on interethnic and regional problems. Jews were also overrepresented among the wealthiest businessman of post-Soviet Russia, the so-called oligarchs, who overwhelmingly supported Yeltsin. ${ }^{100}$ A person of Jewish origin even became prime minister toward the end of Yeltsin's tenure. ${ }^{101}$ Jews were also the most commonly mentioned ethnic group for their suffering as a result of the policy of passport ethnicity. ${ }^{102}$ Among other ethnic groups that suffered significantly from this policy, one can count Germans. Their Volga German ASSR was

\footnotetext{
${ }^{98}$ Jewish members of Yeltsin's governments included the following: Emil Pain, Boris Berezovskiy, Boris Nemtsov, Yakov Urinson, Alexander Livshits, Mikhail Komissar, Ephim Basin, Zinovy Pak, Evgeniy Yasin (Aron 2000, 723). Another source adds Anatoly Chubais, Sergey Kiriyenko, Pyotr Aven, and Yevgeny Sapiro (Krichevsky 2005). According to the Russian census of 2002, there were only 229,938 Jews in Russia, corresponding to 0.16 percent of the total population, which highlights the unusual overrepresentation of Jews within the political and economic elite under Yeltsin (Perepis Naseleniia 2002). For the rise and fall of Jewish prominence in early Soviet politics, see Slezkine 2004.

${ }^{99}$ Rahr 1984. That one person was Veniamin Emanuilovich Dymshits, deputy chairman of the USSR Council of Ministers and a full member of the Central Committee of the CPSU.

${ }^{100}$ Aron 2000, 528, 594-97, 609-10, 624; Colton 2008, 403-4; Goldman 2000; Hoffman 2002.

${ }^{101}$ Goldman 2000, and personal communication. This person was Primakov.

102 Hoffman 1997; Tishkov 1997a.
} 
abolished before World War II, they were deported en masse to Kazakhstan to live in "special settlements" under terrible conditions, and their ethnic identification continued to function as a disadvantage. ${ }^{103}$ Political representation of Germans also improved under Yeltsin, in contrast to the early 1980s, when there was not a single ethnic German among the top one hundred officials of the USSR. ${ }^{104}$

In addition, a few prominent public intellectuals, such as Starovoitova and Tishkov, suggested that the ethnic Russian majority, which constituted 78 percent of the population, was disadvantaged in political appointments in the ethnic republics. ${ }^{105}$ Russians, Jews, Germans, and other ethnic groups who suffered from passport ethnicity, then, were perceived to have interests in conflict with the interests of titular ethnic groups in the autonomous regions such as Chechens, Ingush, Tatars, Kabardins, Balkars, and others perceived to benefit from passport ethnicity.

Yeltsin adopted a liberal form of territorial nationalism, according to which inscribing ethnic origins in passports was anathema. Already in the last months of the USSR, removal of ethnicity from the internal passport was proposed in the USSR Supreme Soviet prepared by the parliament's Joint Committee on Legislation and Law and Order. It met with spirited resistance, however, especially from the Central Asian deputies. ${ }^{106}$ Valery Tishkov, the minister of nationalities and the director of the Institute of Ethnology and Anthropology, provided the Yeltsin elite with much-needed intellectual justification and a new liberal nationalist discourse on this issue. Tishkov strongly and publicly advocated removing ethnicity from the passport. ${ }^{107} \mathrm{It}$ is revealing, however, that this change came in 1997 and not in 1992, when Tishkov was the minister. Yeltsin's power over his opponents was most disproportionate in 1997 . He had already destroyed the communist-dominated Russian Supreme Soviet in 1993, and he defeated his communist rival, Zyuganov, in the presidential election of 1996 . He thus had a year without a serious political rival in this period, before the 1998 Russian

\footnotetext{
${ }^{103}$ Mukhina 2007.

${ }^{104}$ For the early 1980s, see Rahr 1984. Ethnic Germans in Yeltsin's cabinets included Alfred Kokh, minister for privatization, and Georgii Boos, minister of taxes. Eduard Rossel, the governor of Yeltsin's home province, Sverdlovsk, and an ally of Yeltsin, was also ethnic German. Yeltsin appointed Viktor Kress, another ethnic German, as governor of Tomsk in 1991, a position that Kress held since then. In the 2002 census, ethnic Germans numbered 597,212 people, corresponding to 0.4 percent of the population. Perepis Naseleniia 2002.

105 Tishkov 1997a; Evangelista 1999, 287.

106 Stepovoi and Chugayev 1991.

${ }^{107}$ Among others, see Tishkov 1997a; and Tishkov 1997b.
} 
economic crisis eroded his popularity. The Yeltsin period, and in particular 1997, was therefore the time when all three elements of ethnic regime change finally coincided.

Neither the 1996 presidential elections nor any other political campaign in Russia revolved around the removal of ethnicity from the passport, which was never as central a political issue as citizenship was in Germany or as minority languages were in Turkey. Hence, passport reform is completely absent from Yeltsin's autobiographical writings and from almost all of his biographies in English. ${ }^{108}$ Instead, the 1996 elections pitted a virulently ethnic Russian nationalist, Zyuganov, against a more civic nationalist, Yeltsin. Not only did Yeltsin receive overwhelming support from Jewish voters, as well as financial, intellectual, and political support from prominent Russian Jews throughout his campaign, but even in the ethnic autonomous republics he received an 8 percent larger share of the votes than Zyuganov. ${ }^{109}$

On March 13, 1997, Yeltsin eliminated ethnicity in the internal passport with a presidential decree (no. 232), "On the Basic Document Certifying the Identity of Russian Federation Citizen on the Territory of the Russian Federation." 110 This decision alleviated the ethnic grievances of Jews and other discriminated minorities, but, as expected, it was greeted with protests by the political leadership in Tatarstan, Bashkortostan, Ingushetia, and some other regions. ${ }^{111}$ Nonetheless, the reform was successfully implemented. (See Table 9.)

The most articulate spokesperson on behalf of the reform was Tishkov, not Yeltsin. In Tishkov's words: "Russia faces the problem of achieving general civil allegiance and overcoming the rigid official division of citizens into ethnic categories, which provokes conflicts." $\mathrm{He}$ considered removal of ethnicity from the passport to be, "a modest but important step" in solving the problem. ${ }^{112}$ For Tishkov, a supraethnic, civil allegiance to the new Russian state was considered a sine qua non of state- and nation-building. In urging the government to implement the reform despite protests from some republics, Tishkov argued that

\footnotetext{
108 Yeltsin 2000 and Colton 2008 do not mention passport reform at all. An exception is Leon Aron, who briefly discusses the sense of relief and joy among Jews upon the removal of ethnicity from the passport but who does not discuss what, if anything, Yeltsin has thought, written, or said on this issue. Aron 2000, 723-24.

${ }^{109}$ For Zyuganov's virulent anti-Semitism and overwhelming Jewish support for Yeltsin in the 1996 presidential elections, see Aron 2000, 579-633. For the election results in ethnic autonomous regions, see Marsh and Warhola 2000, 33-34.

${ }^{110}$ Sadkovskaya 1997.

${ }^{111}$ Hoffman 1997; Aksyonov and Gulko 1997.

${ }^{112}$ Tishkov 1997a.
} 
TABLE 9

Unsuccessful and Successful Attempts to Change the Multiethnic Regime in the Soviet Union and the Russian Federation, 1953-97

\begin{tabular}{lcccc}
\hline \hline USSR/RF & Counterelite? & $\begin{array}{c}\text { Nerw } \\
\text { Discourse? }\end{array}$ & Hegemony? & Change? \\
\hline Khrushchev, 1957-64 & yes & no & no & no \\
Brezhnev, 1964-82 & no & yes & no & no \\
Andropov, 1982-83 & yes & yes & no & no \\
Gorbachev, 1985-91 & no & yes & no & no \\
Yeltsin, 1991-96 & yes & yes & no & no \\
Yeltsin, 1997 & yes & yes & yes & yes \\
\hline
\end{tabular}

“it's absolutely clear that there should be no 'nationality' line in the Russian passport. If the authorities give in on this matter, Russia will spend another 30 or 40 years trying to build a state, and the outcome will be uncertain." 113 Tishkov was drawing an implicit parallel with the perceived failure of Soviet state building witnessed by the dissolution of the USSR along ethnic federal lines; Russia had to avoid this outcome. This was most consistent with Tishkov's advocacy of a new, civic Rossian nationhood and nationalism that would transcend ethnic differences. ${ }^{114}$ His discourse was a justification for Russia's transition from a multiethnic to an antiethnic regime, and the passport reform was a successful undertaking in that direction.

TurkeY, 1950-2009

The Democratic Party that swept to power with the first free and fair elections in 1950 was a counterelite. The DP repudiated many aspects of Kemalism, and it represented ethnic constituencies, such as the Kurds and the Alevis, that resented Kemalist policies on ethnicity. The party included among its ranks many Kurdish and Alevi notables ${ }^{115}$ and had

${ }^{113}$ Tishkov 1997b.

${ }^{114}$ Tishkov 1997c.

${ }^{115}$ Interviews include Akşener 2007; Aktaş 2007; Ateş 2007; Bekaroğlu 2007; Belge 2007; Bucak 2007; Çamuroğlu 2007; Ekinci 2007; İlhan 2008; Kutlay 2007; Oran 2007; Yaman 2007; and Yıldırım 2007. Meral Akşener, Turkish nationalist politician, member and deputy speaker of the parliament (MHP, 2007-present); minister of interior (DYP, 1996-97); Mehmet Bekaroğlu, Islamist politician, member of the parliament (RP, 1999-2002), and deputy chairman of the Felicity Party (SP); Reha Çamuroğlu, Alevi member of the parliament (AKP, 2007-present); Sertaç Bucak, chairman of the Kurdish nationalist Party of Rights and Freedoms (HAK-PAR); Tarik Ziya Ekinci, Kurdish socialist, member of the parliament (TIP, 1965-69), representing Diyarbakır; Naci Kutlay, Kurdish socialist public intellectual and politician, deputy chairman of Democratic People's Party (DTP); Baskın Oran, socialist public intellectual and independent candidate for Istanbul in 2007 elections; Toktamış Ateş, Kemalist public intellectual and columnist; Murat Belge, socialist public intellectual and columnist; Ali Aktaş, Ali Yaman, Ali Yıldırım, and Faysal İlhan, Alevi scholars and activists of different political orientations. 
disproportionate power over its opponents throughout the decade, even capturing 93 percent of the seats in the parliament (502 out of 541) in its second term (1954-57). However, the DP was ill equipped ideologically to provide any new thinking about ethnicity and nationality. Though it made some symbolic gestures toward the Kurds and carried the traditional Kurdish and Alevi leadership into the parliament, it did nothing in the way of recognizing ethnic minorities and their cultural differences.

Following the military coup of 1960 , there emerged several new parties that relied on ethnic electoral support from those who resented state policies on ethnicity. The New Turkey Party (YTP), the Unity Party (TBP), and the Labor Party (TIP) are the most prominent examples of this type, with Kurdish and Alevi electoral support. The rhetoric of TIP candidates from eastern provinces such as Tar1k Ziya Ekinci popularized the (Soviet) socialist idiom, "brotherhood of peoples,"116 highlighting Turkey's ethnic diversity and breaking the official taboo against using multiple categories in discussing Turkey's population. ${ }^{117}$ This period was akin to the ideological gestation period in Germany (1982-98) and in the Soviet Union (1953-80), when new ideas on ethnicity and nationhood developed. Alevis and Kurds articulated the problems they faced due to their ethnicity and formulated their claims for recognition in ideological terms. In the 1960s and 1970s this ideological discussion occurred mostly in leftist politics, as part of the Marxist-Leninist analysis. In the 1970s Islamists developed their own critique of Kemalism, including of its ethnic policies, and articulated an Islamist vision of multiculturalism. These parties were either in the opposition or at most junior partners in coalition governments; hence, they did not have much power to act on their critiques. The 1980 military coup then destroyed the political left and to a lesser extent damaged political Islamism.

Ethnic politics in the post-1980 period were strongly influenced by the terrorist guerrilla insurgency of the PKK, which raged for fifteen years (1984-99) until its leader was captured and imprisoned, and then continued in a muted fashion. The PKK's impact on the prospects of reform has been regressive: the formation of its political wing led to the segregation of Kurdish representatives in Turkish politics and doomed them permanently to be a small opposition party with no access to

\footnotetext{
${ }^{116}$ The Kurdish translation of this slogan (biratiya gelan) was also popularized by socialists.

${ }^{117}$ Burkay 1969: "If our Western laborer brothers are oppressed once, our Eastern brother is oppressed twice, or thrice. Oppressed because of his language, and belief system. When it comes to the East, governments ... treat the people like a colonial people.... Long live the brotherhood and freedom of peoples!" See also Ekinci 1969.
} 
executive power. Moreover, the PKK's use of terrorism stigmatized any multiculturalist reform as a concession to terrorism, making change even more difficult. In the 1980s and early 1990s the Social Democratic Populist Party (SHP) represented ethnically assertive Kurds and Alevis and as such was a counterelite. The sHP also engaged in a leftist ideological rethinking of ethnicity and the nation and became a junior partner in a coalition government with the DYP (1991-95). The SHP proposed far-reaching reforms in the areas of publishing, broadcasting, and education in minority languages. ${ }^{118}$ However, the party thoroughly failed, and none of its promises were realized. Moreover, their government witnessed the worst fighting between the Turkish military and the PKK. The SHP failed because it lacked sufficient political power to push through a change in the ethnicity regime: it was only the junior partner in a coalition government, controlling about one-fifth of the parliament, without even a simple majority, let alone a hegemonic majority. Likewise, the Islamist Welfare Party's (RP) short-lived coalition government with DYP (1996-97) did not lead to change in state policies on ethnicity. Although RP was the larger coalition partner with Erbakan as the prime minister, DYP and other parties in the parliament were positioned against reform.

The 1990s witnessed heightened activity among Islamist public intellectuals articulating a vision of a pluralist society with Islam as its guiding principle. ${ }^{119}$ The debate surrounding the "Medina Contract," wherein the Prophet Mohammed guaranteed the freedoms of Jews and Christians in the first Muslim society of Medina, involved not only Islamists but also liberal and leftist intellectuals. ${ }^{120}$ The RP's vision of an Islamic ummah (Islamic community/nation) promised to grant the cultural and linguistic rights of Kurds, Arabs, Lazes, Circassians, and other ethnic groups. The RP leader, Erbakan, argued that "the establishment of Islamic brotherhood is the first step in the solution [of PKK terrorism]." ${ }^{121}$ Speaking in the heavily Kurdish populated province of Bingöl, Erbakan claimed that, "even though for centuries children of this country began school with besmele [in the name of God ... ], you removed besmele. What did you put instead? 'I'm a Turk, I'm right, I'm

118 твмм 1991, Appendix 3.

${ }^{119}$ Bulaç 1992.

${ }^{120}$ Bulaç 1992; Ege 1993; Sarıbay 1993.

${ }^{121}$ Refah Partisi n.d., 42. Speaking about the roots of Kurdish separatist terrorism, Erbakan continued: "Why this [terrorism] did not exist throughout history and yet exists today? Because throughout history there was a fundamental component binding us together, Islamic brotherhood. This was abandoned, and materialist politics were chosen, and vacuum of belief could not be filled. Today's suffering and pain is the result"; emphasis in the original. 
hardworking." 122 Saying this entitled a Muslim child of Kurdish origin to reply, "Is that so? Then I'm a Kurd, I'm more right, and I'm more hardworking." ${ }^{23}$ The RP's approach to the ethnic question was a frontal attack on the Kemalist ethnicity regime premised on assimilation.

The AKP came to power in November 2002. Having Islamist roots and a leader who was imprisoned for reciting a poem, the party was a counterelite: it repudiated many aspects of Kemalism and represented ethnic constituencies, mostly Kurdish, that resented state policies on ethnicity. Moreover, the AKP provided an Islamist multiculturalist new thinking about ethnicity. ${ }^{124}$ Finally, it had a two-thirds majority in the parliament. In 2004 AKP initiated broadcasting in Arabic, Bosnian, Circassian, Kurdish, and Zaza, the five largest minority languages, followed by an entirely state-funded Kurdish-language television channel in January 2009. (See Table 10.) ${ }^{125}$ This was accompanied by measures that amounted to semiofficial recognition of the Alevi belief system in the process of the AKP's "Alevi opening." ${ }^{26}$

There was also substantial input from liberal scholars to the AKP's reform effort. ${ }^{127}$ However, the party's massive grassroots support for minority reforms, in particular the "Kurdish opening," was clearly based on Islamic brotherhood, not Western liberalism. ${ }^{128}$ It is also true that the interests of the AKP and the EU coincided on minority reforms, but the decisive and differentiating factor in this episode was the AKP's interests and not those of the EU. Two comparisons across parties and over time illustrate this point: in both the 1999 and the 2002 elections, all major political parties that cleared the 10 percent threshold

${ }^{122}$ A famous saying of Atatürk.

${ }^{123}$ Calmuk 2001, 8 .

${ }_{124}$ Among countless examples of the Islamist multiculturalist discourse among columnists supportive of AKP's minority reforms, see Albayrak 2007a; Albayrak 2007b; Armağan 2007; and Kaplan 2007.

${ }^{125}$ Hürriyet 2009.

126 Çamuroğlu 2007. See also NTVMSNBC 2009; and Radikal 2009. AKP organized multiple and highly publicized Alevi workshops aimed to understand and solve the problems Alevis face. In December 2009, during the Muharram fast of the Alevis, state television broadcast a documentary series exploring the beliefs, rituals, and historical development of Alevis.

${ }^{127}$ Prominent among them were the self-identified advocates of a "Second Republic" (İkinci Cumburiyetçiler), who demanded a more liberal approach to the economy, culture, and religion. For a description of this movement, see their Web site, <http://www.ikincicumhuriyet.org>, accessed May 19, 2010.

${ }^{128}$ In a spectacular illustration of the Islamist discourse supporting the Kurdish opening, a daily newspaper supportive of AKP suggested in its headline that the "roadmap" and inspiration of AKP's Kurdish opening is the Farewell Address of the Prophet Muhammad in 632, in which he condemned racism and ethnocentrism [kavmiyetçilik] (Vakit 2009). Although Vakit is an Islamist newspaper that is not fully representative of AKP's position, it nonetheless represents an important segment of religious conservative supporters of AKP at the grassroots level. For similarly Islamist sentiments expressed about Kurds and ethnic diversity in other, more popular newspapers sympathetic to AKP, see the references from Yeni Safak and Zaman cited in the previous footnotes. 
TABLE 10

Unsuccessful and Successful Attempts to Change the Antiethnic Regime in Turkey, 1950-2009

\begin{tabular}{lcccc}
\hline \hline Turkey & \multicolumn{4}{c}{ New } \\
Counterelite? & Discourse? & Hegemony? & Change? \\
\hline 1950-60 (DP) & yes & no & yes & no \\
1960-90 (various) & no & no & no & no \\
1990-96 (SHP, RP) & yes & yes & no & no \\
1997-2002 (DSP-led & no & no & no & no \\
$\quad$ coalitions) & & & & yes \\
2002-2009 (AKP) & yes & yes & yes & yes \\
\hline
\end{tabular}

for entering parliament, with the partial exception of the nationalist MHP, were supportive of EU accession as a general rule. If there was an overlap of EU demands and the programs of political parties, this was also true of some parties other than AKP, including those that formed previous governments. Even the nationalist MHP undersigned many pro-EU reforms, including Turkey's acceptance of international arbitration, but resisted broadcasting and education in minority languages. ${ }^{129}$ Second, AKP undertook the most radical and far reaching of its minority reforms, including the opening of TRT 6, after 2007, when public enthusiasm and belief in the possibility of Turkey's accession to the EU was at an all-time low. ${ }^{130}$

The PKK's behavior changed after the capture of its leader, Abdullah Öcalan, in Kenya in February 1999. Öcalan has been serving a life sentence since then. Compared with the early 1990s, when the PKK controlled large swaths of territory, by the time of Öcalan's capture it was already militarily defeated; having no safe haven in Turkey, it operated out of Iraq and Syria. Nonetheless, the PKK declared a unilateral ceasefire on August 1, 1999, which lasted until June 2004. ${ }^{131}$ These major changes in the PKK's behavior occurred under the minority government of Ecevit's DSP and the DSP-led coalition government that ruled between 1999 and 2002. However, the Kurdish and other minority reforms on

\footnotetext{
${ }^{129}$ For Turkey's acceptance of international arbitration under MHP government in 2001, see TBMM 2001. For MHP's resistance to EU demands on minority reforms and in particular Kurdish language, see Neşe Düzel's interview with Şevket Bülent Yahnici, the deputy chairman of MHP (Düzel 2001). Yahnici specifically argues that granting the cultural rights that the EU demands would lead to Turkey's territorial dissolution.

${ }^{130}$ In response to the question of whether they would vote for Turkey's EU membership in a referendum, only 50 percent of Turks said they would in 2007, the lowest ever in this decade-long survey. After a slight upsurge in 2008, this support dipped to a new historic low in 2009 with only 46 percent of Turks supporting Turkey's EU membership. Aktürk 2007; Ergin 2010.

${ }^{131}$ Uslu 2007.
} 
which we focus here occurred between 2004 and 2010 under the AKP governments (2002-present), in particular in 2009, with precedents in 2004. Hence, changes within the PKK, which preceded the AKP governments by about four years, cannot account for the reforms.

Following Öcalan's imprisonment and the PKK's military defeat, Turkey's defense expenditures declined from 10.5 percent of the total budget in 1997 to 8.8 percent in 2000 and 6.8 percent in 2001, and they have continued to fluctuate in the 6-7 percent range since then. ${ }^{132}$ Already by 2000 the military-economic costs of Kurdish separatist terrorism were significantly lowered. A scholar of comparative politics and Kurdish nationalism concluded that "[i]n the late 1990s, the Turkish state defeated the insurgent organization PKK militarily, without making any important concessions to Kurdish nationalism," demonstrating the success of a military solution. ${ }^{133}$ It was almost six years after Öcalan's capture that Turkish state television began broadcasting in Arabic, Bosnian, Circassian, Kurdish, and Zaza, and it was only in 2009 that an entirely new state channel exclusively broadcasting in Kurdish was inaugurated. In short, the timing and the nature of reforms implemented by the AKP government cannot be plausibly explained by differences in the cost of repression over time.

\section{The Limits of My Argument: The Origins of Ethnicity Regimes and the Preconditions of Change}

In this article I have argued that the coincidence of three factors explains change in ethnicity regimes. (See Table 11.) My argument traces continuity and change in certain state policies on ethnicity in three countries over time, but I do not claim that it would also explain the origins of the ethnicity regimes in these or other countries. It is tempting to make precisely such an argument, since a cursory look at the origins of ethnicity regimes in Turkey and the Soviet Union in particular seems to support the argument that radically new counterelites (Bolsheviks and Kemalists) opposing the ancien régime, armed with new discourses on ethnicity and nationhood (Leninism and Kemalism), assumed disproportionate, hegemonic power over their opponents in domestic politics for many decades and radically overhauled state policies on ethnicity. I neither favor nor oppose such a characterization, but the limitations of this article do not allow for a detailed examination of

\footnotetext{
${ }^{132}$ Hürriyet 2010.
}

${ }^{133}$ Kocher 2002, 1. 


\section{TABLe 11}

Successful Change in State Policies on Ethnicity: Germany, Russia, AND TURKEY

\begin{tabular}{|c|c|c|c|c|}
\hline Country & Counterelite & New Discourse & $\begin{array}{l}\text { Hegemonic } \\
\text { Majority }\end{array}$ & $\begin{array}{l}\text { Content of the } \\
\text { Reform }\end{array}$ \\
\hline Germany & $\begin{array}{l}\text { SPD-Green } \\
\text { government } \\
(1998-2005) \\
\text { supported by } \\
\text { FDP and PDS }\end{array}$ & $\begin{array}{l}\text { assimilationism } \\
\text { ("Germany is } \\
\text { a country of } \\
\text { immigration") }\end{array}$ & $\begin{array}{l}\text { SPD }(298) \\
+ \text { Greens }(47) \\
\quad+\mathrm{FDP}(43)+\mathrm{PDS}(36) \\
\quad=424 \mathrm{CDU} / \mathrm{CSU}= \\
245\end{array}$ & $\begin{array}{l}\text { citizenship } \\
\text { reform } \\
\text { (passed by } \\
365 \text { to } 182 \text { ) }\end{array}$ \\
\hline Russia & $\begin{array}{l}\text { Yeltsin } \\
\text { presidency } \\
\quad(1992-2000)\end{array}$ & $\begin{array}{l}\text { Rossiian } \\
\text { nationalism }\end{array}$ & $\begin{array}{l}58 \% \text { (Yeltsin) vs. } \\
\quad 40 \% \text { (Zyuganov) }\end{array}$ & $\begin{array}{l}\text { passport } \\
\text { reform }\end{array}$ \\
\hline Turkey & $\begin{array}{l}\text { AKP government } \\
\quad(2002-\text { present })\end{array}$ & $\begin{array}{l}\text { Islamic multi- } \\
\text { culturalism }\end{array}$ & $\begin{array}{l}\mathrm{AKP}=365 \mathrm{vs} . \\
\quad \mathrm{CHP}=177 \mathrm{MPs}\end{array}$ & $\begin{array}{l}\text { minority } \\
\text { languages } \\
\text { reform }\end{array}$ \\
\hline
\end{tabular}

the founding period of ethnicity regimes in these cases. Suffice it to say, however, that military conflict, violence, and repression related to World War I and its aftermath played a much greater role in these founding moments than has been the case in the failed and successful attempts to change state policies on ethnicity in the second half of the twentieth century that I have focused on. This difference renders a comparison with the relatively peaceful and democratic process of change later on somewhat problematic. Lenin and Ataturk did not need an electoral mandate for their radical overhauling of state policies on ethnicity in the transition from the Tsarist and Ottoman Empires to the Soviet Union and the Turkish Republic, respectively. It is difficult to say that their political "hegemony" was of the same nature as the exceptionally large parliamentary majorities that Gerhard Schröder and Tayyip Erdoğan commanded eight decades later.

The contrast between undemocratic origins and democratic evolution over time in Germany, Turkey, and Russia highlights another point made earlier in this article: it is very difficult to change multiple aspects of the ethnicity regime at once in a democratic context; hence, change occurred primarily in one key policy area of interest in each case. In the view of the current author, it is almost impossible under democratic conditions to change as many state policies on ethnicity and as radically as Lenin and Ataturk did in the 1920s. This brief historical contrast sheds some light on the question of why the historic changes 
on state policies that occurred after half a century of failed efforts have nonetheless been limited in their nature.

The conditions, if there are any, that facilitate the coincidence of the three necessary and sufficient elements of change (counterelites, new discourses, hegemony) are likewise beyond the scope of my argument. It is tempting to suggest that international shocks, such as World War I or the end of the cold war, facilitate the coincidence of these three elements. However, the Second World War and the onset of the cold war, too, are massive international shocks, especially in the German and Soviet cases, and yet a change in the German citizenship law and Soviet passport ethnicity is conspicuously absent in the immediate aftermath of World War II. It is also tempting to suggest that single-member district (SMD) electoral systems are more conducive to change because of their propensity to yield large parliamentary majorities, but this contradicts the Turkish experience, since Turkey had an SMD electoral system until the 1960 military coup, yet that is not when change in the ethnicity regime occurred. It is impossible to discuss all the potential external and domestic preconditions that might facilitate the coincidence of counterelites, new discourses, and hegemonic majorities, but the comparative political historical analysis provided in this article suggests that what brings these three elements together is historical contingency.

\section{Persistence and Transformation in Regimes of Ethnicity: Contributions to Political Science and Comparative Politics of Ethnicity and Nationhood}

This article has provided an institutionalist account of nationhood by conceptualizing state policies on ethnicity as "ethnicity regimes." As such, its main conclusions pertain to the debates on institutional change and persistence. The nature of key concepts of new institutionalism such as "path dependence" and "critical junctures" acquire new meaning through this study. When new "clients" with different ethnic backgrounds and interests enter the institution of nationhood through education, employment, and politics, and when these new clients have a different, critical, revisionist perspective towards these policies than their predecessors, and when this critical outlook is joined with a new ideology, the only obstacle to transforming those institutions is a large enough margin of victory against opponents of change. In this sense, critical junctures do not just happen but, rather, they are constructed by the conscious actions of political actors over long periods of time as 
part of a deliberate strategy, with the hope of creating that very critical juncture. However, one political organization usually cannot control all the processes whose coincidence creates the critical juncture; they can, however, work to coordinate with other actors to that end.

Ethnicity regimes are one of the most path-dependent bundles of policies and institutions. It is surprising that they attracted a smaller share of the attention in the studies on path dependence than, for example, welfare state regimes. My study has attempted to fill that gap. Once put in place in the early twentieth century in Germany, the Soviet Union, and Turkey, a set of policies on ethnicity persisted for eight decades, despite significant political challenges, elite initiatives, and societal demands for reform. This side of the story has significant implications for political science.

The other side of the story indicates that, although very difficult and rare, these institutions can change. This is an important corrective to the belief, implied or explicitly stated by many scholars of ethnicity and nationalism, that the nation-state has certain policies on ethnicity and that these policies are an immutable part of its existence. The implication of such a depiction is that the state has to collapse or disintegrate in order for these policies to change. This is false. Likewise, this study demonstrates the falsehood of a dichotomous view of the choices that ethnic minorities have in a nation-state, expressed by Gellner among others, between "assimilation" and "secession/border change":

Under the new social regime, this [condition of minorities] became increasingly uncomfortable. Men [of minority backgrounds] then had two options, if they were to diminish such discomfort: they could change their own culture, or they could change the nature of the political unit, either by changing its boundaries or by changing its cultural identification. ${ }^{134}$

The study of ethnicity regimes in Germany, Russia, and Turkey demonstrates that this dichotomy is false and misleading, as there is another option: one could change the policies and institutions of the state regarding ethnic diversity, as opposed to changing the "boundaries" of the state (nature of the political unit) or "assimilating" its minorities. It is surprising that scholars such as Gellner, who knew of countries such as the United Kingdom and Canada, which accommodated ethnic, linguistic, and religious diversity to varying degrees including ethnic federalism (for example, Scotland and Quebec), could suggest

${ }^{134}$ Gellner 1994, 108. 
only the two options - of boundary change and assimilation-for the minorities. ${ }^{135}$

The explanatory framework of change and persistence in ethnicity regimes that constitutes my main argument, based on the coincidence of counterelites, new discourses on ethnicity and nationhood, and political hegemony, can be employed, tested, and modified in studying other comparable cases of significant change in state policies toward ethnic diversity. Spain, during its transition to democracy in the late 1970s and the early 1980s, went through a radical reorganization of its administrative structures to give wider autonomy and ethnic, cultural, and linguistic rights to its subnational units including Catalonia and the Basque country. ${ }^{136}$ Britain, under the leadership of Tony Blair's Labor Party in the late 1990s, went through some of the most radical changes in its recent history with the "devolution" of powers to Scotland and Wales. ${ }^{137}$ India went through changes in its federal structure by creating new federal units along ethnolinguistic lines. ${ }^{138}$ The United States moved away from a classical antiethnic regime based on assimilation ("melting pot") toward a more multiethnic regime with affirmative action policies since the 1960s. ${ }^{139}$ Further research on other countries that went through significant changes in state policies toward ethnicity would enrich our understanding of the dynamics of persistence and change in regimes of ethnicity.

Despite the changes occurring at the end of the twentieth century, the extreme difficulty of bringing about those changes through protracted struggles, major setbacks, and multiple failures demonstrated the resilience of ethnicity regimes rather than their malleability. For all the many debates on superseding the nation-state through processes of globalization, one observes that most Turks in Germany do not have citizenship rights while most Algerians in France do; and while Muslims in Switzerland, Slovenia, or Greece faced significant obstacles when they wanted to build a mosque with a minaret, Muslims in England and the United States did not. ${ }^{140}$ Persistence, more than change, captures the overall spirit of ethnicity regimes across cases and time.

${ }^{135}$ Fossum, Poirier, and Magnette 2009.

${ }^{136}$ For the transition to democracy and the devolution, see Conversi 1997, 141-61.

${ }^{137}$ McDonald 2007.

${ }^{138}$ However, the creation of new states along ethnolinguistic lines in an already ethnofederal state alone does not amount to a change in the ethnicity regime. Mawdsley 2002.

${ }^{139}$ Graham 1992.

${ }^{140}$ Approaching these issues from a different vantage point, Kuru 2007 also attributes causal importance to "ideological struggles," which is akin to my emphasis on "new discourses on ethnicity and nationhood," in explaining the dynamics of "persistence" in state policies toward religion in the United States, France, and Turkey. 


\section{REFERENCES}

Akşener, Meral. 2007. Interviewed by the author, Istanbul, December 17.

Aksyonov, Sergei, and Nikolai Gulko. 1997. "For 'Line Five,' for the Cause of Peace: Heads of Republics Protest the New Russian Passports." KommersantDaily. October 22: 2. In the Current Digest of Post-Soviet Press 49, no. 42, November 19: 7-8.

Aktaş, Ali. 2007. Interviewed by the author, Adapazarı, Turkey, October 25.

Aktürk, Şener. 2007. "Incompatible Visions of Supra-Nationalism: National Identity in Turkey and the European Union." Archives Européennes de Sociologie 48, no. 2: 347-72.

Albayrak, Hakan. 2007a. “Türkler, Kürtler, gelin büyük düşünelim!” Yeni Şafak. October 30.

- 2007b. "Bu da benim 'GOP’um!” Yeni Şafak. November 28.

Alpbek, Mehmet. 2007. Interviewed by the author, Berlin, January 19.

Arel, Dominique. 2001. "Fixing Ethnicity in Identity Documents: The Rise and Fall of Passport Nationality in Russia.” NCEEER Working Papers, December 12.

Armağan, Mustafa. 2007. "Bave Kurdan: Abdülhamid uğruna ayaklanan Kürtler." Zaman Pazar. November 11.

Aron, Raymond. 2000. Yeltsin: A Revolutionary Life. New York: St. Martin's.

Arutyunov, Sergei. 2007. Interviewed by the author, Moscow, May 4.

Ateş, Toktamış. 2007. Interviewed by the author, Istanbul, December 18.

Bambeck, Manfred, et al. 1982. "Heidelberger Manifest," Frankfurter Rundschau. March 4.

Baran, Riza. 2007. Interviewed by the author, Berlin, January 29.

Beck, Marieluise. 2007. Interviewed by the author, Berlin, February 26.

Bekaroğlu, Mehmet. 2007. Interviewed by the author, Ankara, December 24.

Belge, Murat. 2007. Interviewed by the author, Istanbul, December 19.

Bilinsky, Yaroslav. 1962. "The Soviet Education Laws of 1958-9 and Soviet Nationality Policy." Soviet Studies 14, no. 2: 138-57.

Brenner, Michael. 2007. Interviewed by the author by phone, March 7 .

Brubaker, Rogers. 1992. Citizenship and Nationhood in France and Germany. Cambridge: Harvard University Press.

-1996. Nationalism Reframed: Nationhood and the National Question in the New Europe. New York: Cambridge University Press.

- 2006. Ethnicity without Groups. Cambridge: Harvard University Press.

Bucak, Sertaç. 2007. Interviewed by the author, Ankara, November 29.

Bulaç, Ali. 1992. "Medine Vesikası Hakkında Genel Bilgiler.” Birikim 38-39: 102-11.

Bundesamt für Migration und Flüchtlinge. 2004. Migration, Integration und Asyl in Zablen [Migration, Integration, and Aslyum in Numbers]. Nuremberg: Bundesamt für Migration und Flüchtlinge.

Bundestag. 1980. 8th Legislative Period, 205th Session. March 6.

Bundestag. 1984. 10th Legislative Period, 89th Session. October 5.

Bundestag. 1990. 11th Legislative Period, 195th Session. February 9.

Bundestag. 1999. 14th Legislative Period, 40th Session. May 7.

Bundesvertriebenengesetz (BVFG). 1953. "Gesetz über die Angelegenheiten der 
Vertriebenen und Flüchtlinge. At http://www.bundesrecht.juris.de/bundes recht/bvfg/gesamt.pdf, accessed June 24, 2009.

Burkay, Kemal. 1969. Transcript of radio speech. October 6. TIP file, 0083, serial no. 400.04, folder 14. Tarib Vakfi. Istanbul.

Burlatskii, Fyodor. 2007. Interviewed by the author, Moscow, June 3.

Bürsch, Michael. 2007. Interviewed by the author, Berlin, March 21.

Çalmuk, Fehmi. 2001. Erbakan'ın Kürtleri [Kurds of Erbakan]. Istanbul: Metis.

Çamuroğlu, Reha. 2007. Interviewed by the author, Ankara, November 29.

Ceyhun, Ozan. 2007. Interviewed by the author, Istanbul, October 30.

Checkel, Jeffrey T. 1999. "Norms, Institutions, and National Identity in Contemporary Europe." International Studies Quarterly 43, no. 1 (March): 83-114.

Çınar, Safter. 2007. Interviewed by the author, Berlin, February 1 and March 12.

Colton, Timothy J. 2008. Yeltsin: A Life. New York: Basic Books.

Constitutional Court of Turkey. 1983. Case no.1982/1, decision no.1983/2, April 12.

Conversi, Daniele. 1997. The Basques, the Catalans, and Spain: Alternative Routes to Nationalist Mobilisation. Reno: University of Nevada Press.

Cutler, Robert M. 1980. "Soviet Dissent under Khrushchev: An Analytical Study." Comparative Politics 13, no. 1: 15-35.

Demirbüken-Wegner, Emine. 2007. Interviewed by the author, Berlin, March 22.

Der Tagesspiel. 1981. “Ausländer für Niederlassungsrecht.” May 21.

Deutsche Welle. 2005. “Germany's Struggling Ethnic Minority.” January 9. At http:// www.dw-world.de/dw/article/0,2144,1452170,00.html, accessed June 24, 2009.

Die Zeit. 2006. "Quote für Ausländer." September 4. At http://www.zeit.de/ online/2006/36/integration-migrantenelite, accessed August 24, 2010.

Drobizheva, Leokadia. 2007. Interviewed by the author, Moscow, May 14.

Dündar, Can. 2009. “Kart-kurt, alt-üst oldu,” Milliyet, April 16.

Dündar, Fuat. 1999. Türkiye Nüfus Sayımlarında Azınlıklar [Minorities in the Population Censuses of Turkey]. Istanbul: Doz.

- 2007. Ittihat ve Terakki'nin Müslümanları Iskan Politikası (1913-1918) [The Settlement Policy of the Committee of Union and Progress vis-à-vis Muslims (1913-1918)]. Istanbul: Iletişim.

Düzel, Neşe. 2001. “MHP'den AB'ye: Adım Hıdır, elimden gelen budur.” Radikal. November 26.

Economist. 2001. World in Figures: 2001 Edition. London: Profile Books.

Economist Intelligence Unit (EIU). 2010. The World in 2010: 103-11. At http:// media.economist.com/media/theworldin2010/COUNTRIES_2010_UK.pdf, accessed October 4, 2010.

Editorial. 1965. "Vsemirno-istoricheskaia pobeda sovetskogo naroda." Kommunist, no. 7 (May): 3-14.

- 1966. "Patriotizm i internatsionalizm sovetskogo naroda." Kommunist, no. 9 (June): 3-11.

— 1972. "Sovetskii narod—novaia istoricheskaia obshchnost' liudei." Kommunist, no. 12 (August): 3-14.

- 1976. "Internatsionalizm sovetskogo naroda." Kommunist, no. 13 (September): 13-20.

Ege, Ragıp. 1993. “Medine Vesikası m1, Hukuk Devleti mi?” Birikim 47: 21-39. 
Ekinci, Tarık Ziya. 1969. Transcript of radio speech. September 28. TIP file, 0083, serial no. 400.04, folder 7. Tarih Vakfi, Istanbul.

-2007. Interviewed by the author, Istanbul, November 19.

Elphinston, W. G. 1946. “The Kurdish Question.” International Affairs 22, no. 1: 91-103.

Ergin, Sedat. 2010. "İki akademisyenden hükümet ve muhalefete altın öğütler.” Hürriyet. May 26.

Esping-Andersen, Gosta. 1990. The Three Worlds of Welfare Capitalism. Princeton: Princeton University Press.

Evangelista, Matthew. 1999. "An interview with Galina Starovoytova." PostSoviet Affairs 15, no. 3: 281-90.

Fish, M. Steven. 2005. Democracy Derailed in Russia: The Failure of Open Politics. New York: Cambridge University Press.

Fossum, J. E., J. Poirier, and P. Magnette, eds. 2009. The Ties That Bind: Accommodating Diversity in Canada and the European Union. Brussels: P.I.E. Peter Lang.

Funcke, Liselotte. 1991. "Pressemitteilung von Liselotte Funcke anläßlich ihres Rücktritts als Ausländerbeauftragte der Bundesregierung.” Bonn. June 19.

Gellner, Ernest. 1994. Conditions of Liberty: Civil Society and Its Rivals. New York: Penguin.

Goertz, Gary. 2006. Social Science Concepts: A User's Guide. Princeton: Princeton University Press.

Göktürk, Deniz, David Gramling, and Anton Kaes, eds. 2007. Germany in Transit: Nation and Migration, 1955-2005. Berkeley: University of California Press.

Goldman, Marshall I. 2000. "From Rags to Riches: Jewish Oligarchs in Russia." East European Jerwish Affairs 30, no. 1: 103-13.

Goldstone, Jack A. 2003. "Comparative Historical Analysis and Knowledge Accumulation in the Study of Revolution." In James Mahoney and Dietrich Rueschemeyer, eds., Comparative Historical Analysis in the Social Sciences. New York: Cambridge University Press.

Graham, Hugh Davis. 1992. "The Origins of Affirmative Action: Civil Rights and the Regulatory State." Annals of the American Academy of Political and Social Science 523 (September): 50-62.

Guboglo, Mihail. 2007. Interviewed by the author, Moscow, May 22.

Güçlü, İbrahim. 2007. "Kürtler, toplumsal sözleşme, federalizm ve anayasal vatandaşlik." Rızgari, September 16. At http://www.rizgari.com/modules .php?name=Rizgari_Niviskar\&cmd=read\&id=1149, accessed August 24, 2010.

Halm, Dirk. 2006. "Jeder dritte Türke eingebürgert." Ausländer in Deutschland$A i B$ 04/06. Essen: Zentrum für Türkeistudien.

Hennessy, Eileen N. 1982. "The Heidelberg Manifesto: A German Reaction to Immigration.” Population and Development Review 8, no. 3: 637.

Herbert, Ulrich. 2003. Geschichte der Ausländerpolitik in Deutschland [History of Foreigners Policy in Germany]. Bonn: Bundeszentrale für politische Bildung.

Hirsch, Francine. 2005. Empire of Nations: Ethnographic Knowledge and the Making of the Soviet Union. Ithaca, N.Y.: Cornell University Press.

Hoffman, David. 1997. "Russia's New Internal Passport Drops Nationality, Drawing Praise and Protests." Washington Post. October 25.

. 2002. The Oligarchs: Wealth and Power in the New Russia. New York: Public Affairs. 
Holzberger, Mark. 2007. Interviewed by the author, Berlin, February 22.

Hürriyet. 2009. “TRT'nin Kürtçe kanalı yayına başladı.” January 1.

. 2010. “Türkiye'nin Savunma Bütçesi Düşüyor.” January 27.

Ignitkhanian, M. 1971. "Sovetskii narod-doblestnyi stroitel' kommunizma." Kommunist, no. 6 (April): 9-20.

Ilhan, Faysal. 2008. Interviewed by the author, Berkeley, Calif., April 5.

Immigration and Refugee Board of Canada. 1995. Turkey: Information on Alevis; on whether most Kurds are Alevi; on problems experienced by non-Kurdish Alevis; on whether there is a distinction between the problems experienced by Kurds and by Alevis. October 1. TUR22069.E. At http://www.unhcr.org/refworld/ docid/3ae6ac0040.html, accessed May 15, 2010.

Initiativkreis Gleichberechtigung Integration (IGI). 1981. Yabancıların Yabancılar Politikasına İlişkin Görüşleri [Foreigners' Views on Foreigners Policy]. Berlin: IGI.

Iovchuk, M. 1973. "Internatsionalistskaia kul'tura mnogonatsional'nogo sovetskogo naroda.” Kommunist, no. 3 (February): 49-62.

John, Barbara. 2007. Interviewed by the author, Berlin, March 26.

Joppke, Christian. 2004. "The Retreat of Multiculturalism in the Liberal State: Theory and Policy." British Journal of Sociology 55, no. 2: 237-57.

- 2005. Selecting By Origin: Ethnic Migration in the Liberal State. Cambridge: Harvard University Press.

- 2007. "Transformation of Immigrant Integration: Civic Integration and Antidiscrimination in the Netherlands, France, and Germany." World Politics 59, no. 2 (January): 243-73.

Kaplan, Yusuf. 2007. "Kardeşlik Çağrısı." Yeni Şafak. November 6.

Keddie, Nikki, ed. 1995. Debating Revolutions. New York: NYU Press.

Keskin, Hakk1. 2007. Interviewed by the author, Berlin, February 12.

Khrushchev, Sergei. 2009. Interviewed by the author, Providence, R.I., December 10.

Klepp, Volker. 2007. Interviewed by the author, Berlin, March 7.

Kocher, Matthew. 2002. "The Decline of PKK and the Viability of a One-State Solution in Turkey." International Journal on Multicultural Societies 4, no. 1: 1-20.

Kohn, Hans. 1944. The Idea of Nationalism. New York: Macmillan.

Kolat, Kenan. 2007. Interviewed by the author, Berlin, January 26.

Kommunist. 1977. The New Constitution (Basic Law) of the USSR. no.15 (October): 24-52.

Koopmans, Ruud, Paul Statham, Marco Giugni, and Florence Passy. 2005. Contested Citizenship: Immigration and Cultural Diversity in Europe. Minneapolis: University of Minnesota Press.

KPSS. 1961. XXII s"ezd KPSS: Stenogramma pervogo zasedaniia, October 17-18, Russian State Archive of Contemporary History (RGANI), 1/4/89-91, Moscow.

Krichevsky, Lev. 2005. "Russian Jewish Elites and Anti-Semitism." American Jerwish Committee, May 20. At http://www.ajc.org/site/apps/nlnet/content2.aspx?c =ijITI2PHKoG\&b=838459\&ct=875489, accessed August 25, 2010.

Kühn, Heinz. 1979. Stand und Weiterentwicklung der Integration der Ausländischen Arbeitnehmer und Ibrer Familien in der Bundesrepublik Deutschland: Memorandum des Beauftragten der Bundesregierung [The Current State and Further De- 
velopment of Integration of Foreign Workers and Their Families in the Federal Republic of Germany: Memorandum of the Commissioner of the Federal Government]. Bonn: n.p.

Kuru, Ahmet T. 2007. "Passive and Assertive Secularism: Historical Conditions, Ideological Struggles, and State Policies toward Religion.” World Politics 59, no. 4 (July): 568-94.

Kutlay, Naci. 2007. Interviewed by the author, Ankara, November 22.

Kuvaldin, Viktor. 2007. Interviewed by the author, Moscow, May 29.

Kymlicka, Will. 1995. Multicultural Citizenship: A Liberal Theory of Minority Rights. Oxford: Clarendon Press.

Laurischk, Sibylle. 2007. Interviewed by the author, Berlin, March 23.

Leggewie, Claus. 1990. Multi Kulti: Spielregeln für die Vielvölkerrepublik [MultiCultural: The Rules of the Game for the Multinational Republic]. Nördlingen: Rotbuch.

- 2007. Interviewed by the author by phone, February 28.

Leggewie, Claus, and Zafer Şenocak, eds. 1993. Deutsche Türken: Das Ende der Geduld [German Turks: The End of Patience]. Hamburg: Rowohlt.

Lijphart, Arend. 1977. Democracy in Plural Societies. New Haven: Yale University Press.

Lipman, Masha. 2007. Interviewed by the author, Moscow, May 3.

Mahoney, James, and Dietrich Rueschemeyer. 2003. "Comparative Historical Analysis: Achievements and Agendas." In James Mahoney and Dietrich Rueschemeyer, eds., Comparative Historical Analysis in the Social Sciences. New York: Cambridge University Press.

Marsh, Christopher, and James W. Warhola. 2000. "Ethnicity, Modernization, and Regime Support in Russia's Regions under Yeltsin." Nationalism and Ethnic Politics 6, no. 4: 23-47.

Martin, Terry. 2001. The Affirmative Action Empire: Nations and Nationalism in the Soviet Union, 1923-1939. Ithaca, N.Y.: Cornell University Press.

Mawdsley, Emma. 2002. "Redrawing the Body Politic: Federalism, Regionalism and the Creation of New States in India." Commonwealth and Comparative Politics 40, no. 3: 34-54.

McDonald, Andrew, ed. 2007. Reinventing Britain: Constitutional Change under New Labour. Berkeley: University of California Press.

Mesghena, Mekonnen. 2007. Interviewed by the author, Berlin, March 2.

Miller, Alexei. 2007. Interviewed by the author, Moscow, June 2.

Miller, John H. 1977. "Cadres Policy in Nationality Areas: Recruitment of CPSU First and Second Secretaries in Non-Russian Republics of the USSR." Soviet Studies 29, no. 1: 3-36.

Milliyet. 2007. "55 milyon kişi 'etnik olarak' Türk.” At http://www.milliyet.com .tr/2007/03/22/guncel/agun.html, accessed August 25, 2010

Moore, Barrington, Jr. 1966. Social Origins of Dictatorship and Democracy. Boston: Beacon.

Mukhina, Irina. 2007. The Germans of the Soviet Union. New York: Routledge.

Münz, Rainer. 2007. Interviewed by the author by phone, March 7.

Mutlu, Özcan. 2007. Interviewed by the author, Berlin, February 27.

Mutlu, Servet. 1996. "Ethnic Kurds in Turkey: A Demographic Study." International Journal of Middle Eastern Studies 28, no. 4 (November): 517-41.

Naumkin, Vitaly. 2007. Interviewed by the author, Moscow, May 2. 
Nekrich, Aleksandr. 1978. The Punished Peoples: The Deportation and Fate of Soviet Minorities at the End of the Second World War. New York: Norton. NTVMSNBC. 2009. “TRT'nin ana haber bülteni cemevinde.” January 7. Öney, Bilkay. 2007. Interviewed by the author, Berlin, March 19.

Oran, Baskin. 2007. Interviewed by the author, Ankara, December 26.

Pain, Emil. 2007. Interviewed by the author, Moscow, May 30.

Perepis Naseleniia. 2002. Vserossiiskaia Perepis' Naseleniia 2002 goda [All-Russian Population Census of the Year 2002]. At http://www.perepis2002.ru/index. html?id=17, accessed May 15, 2010.

Pierson, Paul. 2003. "Big, Slow-Moving, and . . Invisible: Macrosocial Processes in the Study of Comparative Politics." In James Mahoney and Dietrich Rueschemeyer, eds., Comparative Historical Analysis in the Social Sciences. New York: Cambridge University Press.

- 2004. Politics in Time: History, Institutions, and Social Analysis. Princeton: Princeton University Press.

Radikal. 2009. "Alevi ders kitabi hazır.” May 13.

Ragin, Charles C. 2000. Fuzzy-Set Social Science. Chicago: University of Chicago Press.

Rahr, Alexander G. 1984. A Biographic Directory of 100 Leading Soviet Officials. Munich: RFE/RL.

Refah Partisi. n.d. Erbakan'ın Konuşmaları: Temmuz 1993 [Erbakan's Speeches: July 1993]. Ankara: Refah Partisi, 1993.

Rogachev, P., and M. Sverdlin. 1963. "Sovetskii narod-Novaia istoricheskaia obshchnost' liudei." Kommunist, no. 9 (June): 11-20.

Sadkovskaya, Tatyana. 1997. "Battles over the Passport," Rossiiskiye vesti, April 1: 2. In the Current Digest of Post-Soviet Press 49, no. 13, April 30: 21-22.

Sadomskaya, Natalia. 1990. "New Soviet Rituals and National Integration." In Henry R. Huttenbach, ed., Soviet Nationality Policies. New York: Mansell.

Sakwa, Richard. 1998. Soviet Politics in Perspective. New York: Routledge.

Sarıbay, Ali Yaşar. 1993. "İslami Popülizm ve Sivil Toplum Arayışı." Birikim 47 (March): 14-20.

Schiffauer, Werner. 2007. Interviewed by the author, Berlin, March 5.

Schmalz-Jacobsen, Cornelia, and Georg Hansen, eds. 1997. Kleines Lexikon der ethnischen Minderbeiten in Deutschland [Small Dictionary of Ethnic Minorities in Germany]. Munich: Beck'sche Reihe.

Schönwälder, Karen. 2001. Einwanderung und ethnische Pluralität [Immigration and Ethnic Pluralism]. Essen: Klartext-Verlag.

- 2007. Interviewed by the author, Berlin, March 14.

Schurmann, Peter. 2007. Interviewed by the author, Cottbus, Germany, March 27.

Scott, James. 1999. Seeing Like a State. New Haven: Yale University Press.

Seferoğlu, Şükrü Kaya. 1982. Anadolu'nun ilk Türk sakinleri Kürtler [The First Turkish Inhabitants of Anatolia: The Kurds]. Ankara: Türk Kültürünü Araştırma Enstitüsü.

Şenocak, Zafer. 2007. Interviewed by the author, Berlin, March 28.

Shnirelman, Victor. 2007. Interviewed by the author, Moscow, May 24.

Skocpol, Theda. 1979. States and Social Revolutions. New York: Cambridge University Press.

Slezkine, Yuri. 1994. “The USSR as a Communal Apartment, or How a Socialist State Promoted Ethnic Particularism.” Slavic Review 53, no. 2 (Summer): 414-52. 
. 2004. The Jewish Century. Princeton: Princeton University Press.

Smith, Anthony D. 1986. The Ethnic Origins of Nations. New York: Blackwell, 1986.

Stepovoi, A., and S. Chugayev. 1991. "Argument on 'Point Five." Izvestia. June 8. In the Current Digest of Post-Soviet Press 43, no. 23 (July 10): 13-14.

TвMм. 1991. Coalition Protocol of the VII. Demirel Government (DYP-SHP). At http://www.tbmm.gov.tr/hukumetler/KP49.htm, accessed August 24, 2010.

- 2001. "Milletleraras1 Tahkim Kanunu," Law no. 4686, approved in June 21. Entered into force upon publication in Resmi Gazete, no. 24453, July 5.

Tishkov, Valery A. 1997a. "Carte Blanche: Farewell to Line Five. The Absence of an Indication of Nationality in a Passport Is a Sign of Democratization, Not Discrimination," Nezavisimaia Gazeta. October 22: 2. In the Current Digest of Post-Soviet Press 49, no. 42, November 19: 10.

.1997b. "Nationalities and the Passport." Izvestia (November 4): 5 . In the Current Digest of Post-Soviet Press 49, no. 44 (December 3): 12.

-1997c. Ethnicity, Nationalism and Conflict in and after the Soviet Union. Thousand Oaks, Calif.: Sage.

. 2007. Interviewed by the author, Moscow, June 5.

Ülker, Erol. 2007. "Assimilation of the Muslim Communities in the First Decade of the Turkish Republic (1923-1934).” European Journal of Turkish Studies. At http://www.ejts.org/document822.html.

Ünsal, Artun. 2002. Türkiye Iş̧̧i Partisi (1961-1971) [Turkey’s Labor Party, 19611971]. Istanbul: Tarih Vakfi Yurt Yayınlar1.

Uslu, Emrullah. 2007. "Turkey's Kurdish Problem: Steps toward a Solution.” Studies in Conflict and Terrorism 30, no. 2: 157-72.

Vakit. 2009. "Yol haritas1 Veda Hutbesi." August 17.

Wehling, Hans-Georg. 1989. “The Bundesrat.” Publius 19, no. 4 (Autumn): 53-64.

Wernicke, Christian. 1989. "Langer Weg zum deutschen Pass.” Die Zeit. March 24. In Deniz Göktürk, David Gramling, and Anton Kaes, eds., Germany in Transit: Nation and Migration, 1955-2005. Berkeley: University of California Press, 2007.

Wüst, Andreas M. 2004. "Naturalised Citizens as Voters: Behavior and Impact." German Politics 13, no. 2: 341-59.

Yaman, Ali. 2007a. Alevilik E̋ Kızılbaşlık Taribi [History of Alevis and Kizilbash]. Istanbul: Nokta Kitap.

. 2007b. Interviewed by the author, Ankara, October 18.

Yeltsin, Boris. 2000. Midnight Diaries. New York: Public Affairs.

Yildırım, Ali. 2007. Interviewed by the author, Ankara, October 18.

Zaslavsky, Victor, and Yuri Luryi. 1979. "The Passport System in the USSR and Changes in Soviet Society." Soviet Union/Union Sovietique 6, no. 2: 137-53.

Zavada, Marina, and Yuri Kulikov. 2006. "Chetyre genseka: Arkadii Vol'skii o Brezhneve, Andropove, Chernenko i Gorbacheve." Kommersant. September 12.

Zimanas, G. 1965. "Internatsional'noe i natsional'noe v zhizni narodov.” Kommunist, no. 6 (April): 52-60.

- 1974. "Politika partii i internatsionalisticheskoe soznanie sovetskogo naroda." Kommunist, no. 5 (March): 45-53.

Zürcher, Erik Jan. 2004. Turkey: A Modern History. New York: I. B. Tauris. 